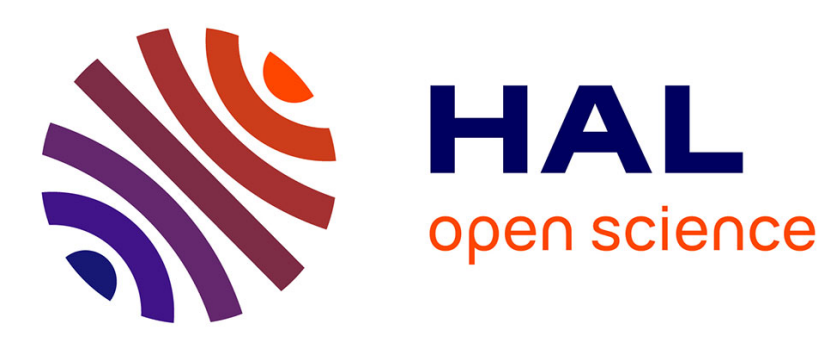

\title{
Brand experience effects on brand attachment: The role of brand trust, age, and income
}

Richard Huaman-Ramirez, Dwight Merunka

\section{To cite this version:}

Richard Huaman-Ramirez, Dwight Merunka. Brand experience effects on brand attachment: The role of brand trust, age, and income: anglais. European Business Review, In press, 31 (5). hal-02118504

\section{HAL Id: hal-02118504 \\ https://hal-amu.archives-ouvertes.fr/hal-02118504}

Submitted on 3 May 2019

HAL is a multi-disciplinary open access archive for the deposit and dissemination of scientific research documents, whether they are published or not. The documents may come from teaching and research institutions in France or abroad, or from public or private research centers.
L'archive ouverte pluridisciplinaire HAL, est destinée au dépôt et à la diffusion de documents scientifiques de niveau recherche, publiés ou non, émanant des établissements d'enseignement et de recherche français ou étrangers, des laboratoires publics ou privés. 
Brand experience effects on brand attachment:

The role of brand trust, age, and income

Richard Huaman Ramirez,

and Dwight Merunka

Accepted for publication in European Business Review, September 2019 


\begin{abstract}
Purpose - The aim of this study is to examine how brand attachment is related to brand experience. The model tests the partial mediating role of brand trust, and the moderating role of age and income.

Design/methodology/approach - 334 participants consuming brands with an experiential offering completed an online questionnaire in a cross-sectional study. The data were analyzed through Partial Least Squares Structural Equation Modeling (PLS-SEM), and advanced methods such as the heterotrait-monotrait ratio and the Henseler's multigroup analysis were used.
\end{abstract}

Findings - Brand experience is positively related to brand attachment, and the more so for younger consumers. This relationship holds for both hedonic and utilitarian brands. Results demonstrate the partial mediation of brand trust in this relationship, especially for utilitarian brands, and with a weaker indirect relationship for high-income consumers.

Research limitations/implications - The research was conducted in one country (Peru). Generalizability of results should be established by carrying out additional studies in other settings or countries.

Practical implications — Experiential marketing both as a positioning strategy and through marketing operations may help brands to increase consumer attachment. This may be managed both through the direct effect of favoring positive experiences, and through the enhancement of brand trust. This is particularly the case for target markets composed of young and low to medium income consumers.

Originality/value - Results confirm the impact of brand experience on brand attachment for both utilitarian and hedonic brands, and establish both the mediating role of brand trust and the moderating role of age and income. These are new insights on the process itself, and on boundary conditions of an important established relationship.

Keywords Brand experience, Brand attachment, Brand trust, Age, Income.

Paper type Research paper 


\section{Introduction}

According to an online study from company MBLM which analyzes emotional connections between consumers and brands, brands with strong connection to consumers generated $\$ 2.9$ billions more in profits compared to those with weak connections (Fortune, 2017). Therefore, brand attachment is an effective brand management objective which results in positive financial performances beyond established consequences such as brand loyalty and price premium (Thomson, McInnis and Whan Park, 2005). Therefore, brands seek to create an emotional connection with customers such as McDonald's with its recent 'I'm lovin' it" slogan displayed both in advertising and on packagings. Achieving brand attachment may be seen as a successful brand strategy, and a better understanding of the process favoring brand attachment is relevant both to the academic and brand management communities.

Brand attachment is one of the main concepts studied in the domain of consumerbrand relationships since it is well established that this emotional bond between consumers and brands has strong and positive consequences on multiple relationships and behaviors such as brand love (Correia-Loureiro et al., 2012), brand loyalty (Japutra et al., 2016), compulsive buying (Japutra et al., 2017), commitment (Belaid and Behi, 2011), ethical judgment (Schmalz and Orth, 2012), satisfaction (Belaid and Behi, 2011), separation distress (Park et al., 2010), proximity maintenance, emotional security, and safer haven (Thomson et al., 2005), purchase intent (Esch et al., 2006), and resilience to negative information (Japutra et al., 2016). Beyond established positive consequences, a main research question is how brand attachment may be favored. Recently, researchers explored potential antecedents of brand attachment such as fear (Dunn and Hoegg, 2014), emotional value (Koronaki et al., 2017), perceived brand responsiveness (Japutra et al., 2016), self-congruence (Malar et al., 2011) or social crowding (Huang et al., 2017). 
However, the experiential perspective has yet been ignored. This holistic perspective is important since it focuses on multiple internal responses from consumers at various brand touch points (Alloza, 2008; Brakus et al., 2009), resulting in complex consumer journeys with the brand (Lemon and Verhoef, 2016). Professional studies suggest that providing experiences to consumers is a top business priority (Accenture, 2015), and that experiences driven from brands may favor attachment (Daniel Newman, 2016). Thus, brand attachment may be affected by these multiple touch points with the brand and by the resulting positive experience consumers enjoy.

From an academic perspective, the fact that brand experience may favor brand attachment was established through two empirical studies. In a context of fashion brands, positive in-store brand experience leads shoppers to develop brand attachment (Dolbec and Chebat, 2013), and in a context of hotel brands, travelers who live a positive experience with brands are more likely to be attached (Kang et al., 2016). However, these studies did not explore the process through which this effect might occur. Research in psychology shows that trust plays a role in the development of attachment (Burke and Stets, 1999; Fraley and Shaver, 2000; Hazan and Shaver; 1994). Other studies established both the influence of trust on commitment (Morgan and Hunt, 1984) and the influence of attachment on commitment (Louis and Lombart, 2010). Therefore, brand experience may not only have a direct effect on brand attachment but also an indirect effect on attachment through brand trust. Moreover, past research on the relationship between brand experience and brand attachment focused on specific brand categories and within countries such as the US and Malaysia. Further studies focusing on a wider range of brand categories and in other contexts will strengthen external validity of the established relationships. 
Also, past studies lacked to explore potential moderating effects on the relationship of brand experience to brand attachment such as the role of individual variables. It could be that the established relationship is stronger or weaker depending on specific individual conditions such as age or income. Recent research revealed the role of age in the emotional aspect of consumption (e.g. emotion in retailing, Loureiro and Roschk, 2013; emotion in advertisement, Drolet et al., 2007; McKay et al., 2011; Williams and Drolet, 2005) and studies on the relationship between age and brand attachment are scarce and focused on adolescents (Bidmon, 2016) or perfume brands (Lambert-Pandraud and Laurent, 2010). Because age influences how individuals experience affect (Birditt and Fingerman, 2003; Diener et al., 1985; Lawton et al., 1992) or display proactive behavior to external stimulation (Gross et al., 1997; Lubin et al., 1988; Steinberg et al., 2008), further attention to the role of age on the relationship between brand experience and brand attachment is warranted. Knowing what consumer age groups are more prone to attach to experiential brands will allow managers to segment the market and better manage consumer behavior.

In addition, research on the influence of income mainly focused on price (GastonBreton and Raghubir, 2013; Mulhern et al., 1998; Rosa-Diaz, 2004; Wakefield and Inman, 2003) or materialism (Ponchio and Aranha, 2008), without considering the context of consumer-brand relationships. While income impacts satisfaction and brand loyalty (Homburg and Giering, 2000, Mishra, 2014), no consideration for brand experience, brand trust or brand attachment was given. The potential effect of income on relationships between brand trust, brand experience and brand attachment deserves attention since individuals of higher income are more likely to behave selfishly (Dubois et al., 2015), and have a general tendency to distrust. Similar to age, income is susceptible to influence the mediating role of brand trust in the relationship between brand experience and brand attachment, since trust is negatively related to income (Judge et al., 1999; Ng et al., 2005). 
Covering these research gaps should allow marketers to better understand through what process brand experience influences brand attachment and to better understand how individual variables may influence the process.

In the current research, we firstly aim at demonstrating that brand experience is positively related to brand attachment. Secondly, we examine the relationship between brand experience and brand attachment through the mediation of brand trust. Thirdly, we investigate the moderating role of age and income on direct or mediated relationships between brand experience and brand attachment.

\section{Theoretical Background and Hypotheses}

\section{Brand Experience}

The notion of experience appears within multiple marketing or consumer contexts: customer experience (Homburg et al., 2017; Jain et al., 2017 for a review; Lemon and Verhoef, 2016), service experience (Chandler and Lusch, 2015; Helkkula, 2011), consumption experience (Holbrook and Hirschman, 1982; Lanier and Rader, 2015), online customer experience (McLean and Wilson, 2016), and brand experience (Brakus et al., 2009). In the context of branding, the brand becomes a moving target in the experience, subject to the whims of the touchpoints between the consumer and the brand (Merrilees, 2017).

Consumers experience brands in any situation of direct or indirect interaction with a branded product or service (Brakus et al., 2009; Kruger, 2018; Morgan-Thomas and Veloutsou, 2013; Schmitt et al., 2015, Trudeau and Shobeiri, 2016). Direct interaction refers to the search for a product or service information, the purchase process, the service or product usage, whereas indirect interaction principally involves advertisement (Japutra and Molinillo, 
2017; Nysveen et al., 2013). In such interactions, brand-related stimuli elicit subjective and internal responses to the consumer's experience. Brand experience is thus defined as the set of responses that consumers evoke at every touch point with brands (Alloza, 2008; Klein et al., 2016) and are stored in long-term memory (Brakus et al., 2009; Roswinanto and Strutton, 2014).

Brand experience refers to sensorial, affective, intellectual, and behavioral responses (Brakus et al., 2009; Ding and Tseng, 2015; Gabisch, 2011; Kang et al., 2016; Merrilees, 2016; Nysveen et al., 2013; Shamim and Butt, 2013; Xie et al., 2017; Zarantonello and Schmitt, 2010, 2013). Sensory brand experience involves the stimulation of senses through exposition to brands (e.g. visual, taste, smell, sound, and touch) (Brakus et al., 2009; Tafesse, 2016). The visual aspect is considered as the most important element of sensory experience because images captured as information are easily stored in consumers' minds (Schifferstein, 2006) and are at stake in any experience with products or services (Beckman et al., 2013; Huang et al., 2015). Visual brand experience provides consumers with an esthetic sense of brands (e.g. brand logos, brand slogans, brand imageries) and their surroundings. However, the relevance of taste, smell, sound, and touch for brand experience depends on the type of product or service offered. Taste and touch are linked to a direct experience with products whereas smell and sound may also be indirectly experienced through the atmosphere created by companies and their brands (Beckman et al., 2013). Affective brand experience includes inner feelings towards brands and emotions evoked when interacting with them (Beckman et al., 2013; Brakus et al., 2009; Huang et al., 2015). This experience is embedded in consumers' minds and generates either positive (e.g. brand love, brand passion) or negative reactions (e.g. brand hate, disgust) (Kang et al., 2016). Intellectual brand experience involves the occurrence of imaginative or analytical thinking by consumers stimulated by brands (Beckman et al., 2013; Brakus et al., 2009). Imaginative thinking entails spontaneity and 
creativity in the generation process of ideas, and analytical thinking emphasizes accuracy and logic in the search for answers to questions (Huang et al., 2015). Behavioral brand experience refers to physical actions elicited by the exposition to brands (Brakus et al., 2009), physical actions representing the use of the body to complete activities triggered by specific stimuli of brands (Kang et al., 2016). The body can thus be used as a source of well-being or health (e.g. sport), as a recreation or expression of emotions (e.g. dancing, jogging), and as a source of symbolic representation (e.g. performances) (Beckman et al., 2013).

Finally, there is a social aspect to brand experience following the experiential marketing framework of Schmitt (1999). Social brand experience refers to a relational component such as relationship with others, and with the ideal self (Gentile et al., 2007, Huang et al., 2015). Relationship with others involves the fact that brands encourage the consumption of products or services together with other individuals, thus creating a link between them through the sharing of space and time (Gentile et al., 2007; Schmitt, 1999; Shamin and Butt, 2013; Tafesse, 2016). The ideal self refers to the assertion of a social identity, generating a sense of social acceptation and distinction from other social groups by means of brands (Gentile et al., 2007).

\section{Brand Experience and Brand Attachment}

The notion of brand attachment is based on Bowlby's (1979) attachment theory, and its definition refers to "an emotion-laden target-specific bond between a consumer and a specific brand" (Thomson et al., 2005). It refers to the emotional bond between a consumer and a brand (Japutra et al., 2016; 2018b; Malar et al., 2011), just as in the relationship between a child and his or her caregiver where attachment is essentially created through strong feelings

(Bowlby, 1979). The cognitive dimension introduced by Park et al. $(2006,2010)$ based on the 
use of brands to create self-image or enhance self-concept refers more to the concept of consumer-brand identification (Escalas and Bettman, 2000, 2003), as indicated by Japutra et al. (2014a), and will not be considered in this research. We follow the view that brand attachment is an effect of the belief that consumers connect with brands (Fedorikhin et al., 2008), and being aware that a brand reflects the self leads individuals to develop over time an emotion-laden bond with it (Japutra et al., 2018a,b; Malar et al., 2011)

Brand attachment is composed of three dimensions: affection, passion, and connection (Thomson et al., 2005; Japutra et al., 2017; Japutra et al., 2018a,b). First, brand affection refers to the warm feelings that a brand creates. This concept is related to Chaudhuri and Holbrook's (2001) brand affect which is defined as the brand's potential to elicit positive emotional response. Brands that render consumers pleasant, joyful and affectionate have an effect on consumer behavior (Matzler et al., 2006). Second, brand passion refers to intense positive feelings that a brand arouses. This concept is in line with subsequent studies that refer to passion as a strong feeling toward the brand (Bauer et al., 2007; Matzler et al., 2007). A passionate consumer becomes involved in an emotional relationship with the brand filled with excitation and obsession (Albert et al., 2013). Third, brand connection involves the feeling of "being linked" to the brand, the feeling of being bonded or joined with the brand.

The fact that consumers are involved in multiple positive brand experiences might increase their attachment to brands. Since the development of attachment is based on interactions between individuals and objects (Baldwin et al., 1996), brands that favor internal responses from consumers at various brand touch points should induce the development of an emotion-laden bond with them. Consumers become attached to brands because of multiple positive experiences (Dolbec and Chebat, 2013; Japutra et al., 2014b; Kang et al., 2016), and brands play a powerful role when being consistently relied upon to provide gratification through experiential elements. Experiencing brands engenders positive responses such as 
contentment and satisfaction (Brakus et al., 2009; Khan et al., 2016a,b; Khan and Fatma, 2017), and this gratification will boost a link between the brand and the consumer since consumers maintain emotional consistency when a brand provides satisfactory experiences (Kang et al., 2016). Finally, since positive experiences lead to good memories (Alloza, 2008; Pine and Gilmore, 1999), living multiple positive brand experiences develops favorable brand memories, which in turn create an attachment toward brands (Cardinale et al., 2016). Based on these arguments, we propose:

H1: Favorable brand experience is positively linked to brand attachment.

\section{The Role of Age in the Relationship between Brand Experience and Brand Attachment}

We propose that the relationship between brand experience and brand attachment is stronger for younger consumers for several reasons. First, age influences the way individuals experience affect. Because of emotional maturity, older individuals experience emotions less intensively than younger individuals (Diener et al., 1985; Lawton et al., 1992). Older individuals have a perception that life taught them to moderate their feelings and to control situations which may lead to emotional overload. In addition, older individuals have a tendency to adapt more easily to emotional events because of repeated exposure (Diener et al., 1985; Larsen and Diener, 1987). The fact of having been exposed to more emotional events leads older individuals to be more habituated and therefore experience affect less intensely. Thus, age may play a role in how brand experience leads to brand attachment.

Second, age influences the proactive behavior displayed to receive external stimulation. Sensation or experience seeking decreases with age (Gross et al., 1997; Lubin et al., 1988; Steinberg et al., 2008), because younger individuals search for stimuli that produce excitement and emotions (Costa and McCrae, 1986). They are more change-oriented and 
carry less conservative propensities (Zuckerman, 1979). Also, younger individuals have higher levels of extraversion, which implies sensation seeking and openness to experience (Costa et al., 1986). Thus, preference for sensory stimulation linked to age may influence the effect of brand experience on brand attachment.

Third, age influences emotional control or regulation (Birditt and Fingerman, 2003; Kessler and Staudinger, 2009; Gross et al., 1997; Lawton et al., 1992; Orgeta, 2009). Older individuals seek to avoid emotional situations and to stay in a neutral state. They exert higher self-control in situations of strong positive or negative feelings. Therefore, the relationship between brand experience and brand attachment should be stronger for younger consumers since they experience more intense emotions in their interactions with brands, are more proactive to receive gratification with external stimulation, and control their emotions to a lesser extent. Since younger consumers seek more interactions with brands and enjoy them more, they should develop more intense attachment toward brands. Based on these arguments, we propose:

H2: The positive link between brand experience and brand attachment is stronger for younger consumers than for older consumers.

The Mediating Role of Brand Trust in the Relationship between Brand Experience and Brand Attachment

We define brand trust as the expectation that consumers have that a brand will consistently deliver its promise. This is based on the evaluative aspect of trust (Mayer et al., 1995) which refers to trust as "the expectations of the trustor that the trustee will perform a particular action important to him or her." The trustor expects that the trustee will accomplish actions for his or her benefit (Doney and Cannon, 1997; Mayer et al., 1995). 
Trust is often modeled as a tri-dimensional concept composed of ability, integrity, and benevolence (Mayer et al., 1995; Schoorman et al., 2007). In our research we focus on ability and benevolence in order to emphasize the cognitive and affective aspects of brand trust ( $\mathrm{Li}$ et al., 2008). Ability, or competence, is related to the capacity that the trustee has to respond to the needs of the trustor (Delgado-Ballester and Munuera-Aleman, 2001; Mayer et al., 1995). The trustee is evaluated by the aptitude to hold promises, and consumers evaluate the ability of a brand to perform its stated function (Chaudhuri and Holbrook, 2001). Benevolence involves the positive intentions of the trustee. The trustor evaluates whether the trustee genuinely wants to do good to him or her. The trustee should demonstrate concern about the welfare of the trustor (Doney and Cannon, 1997), and avoid relying on egocentric motivations for making business with the trustor (Mayer et al., 1995).

Despite the fact that some empirical studies show that concepts linked to brand trust (i.e. brand credibility, partner quality) arise as a consequence of brand experience (FranciscoMaffezzolli et al., 2014; Khan and Fatma, 2017; Shamim and Butt, 2013), the relationship between brand experience and brand trust lacks empirical evidence. We propose that brand trust mediates the relationship between brand experience and brand attachment, for two reasons. First, positive experiences with brands should reinforce the expectation that these brands offer the benefits expected. We argue that since multiple brand experiences provide value and gratification (Brakus et al., 2009), repeated positive brand encounters should reinforce the belief in the capacity of brands to consistently deliver what is expected from them, or even to exceed expectations. Positively experiencing brands should create a perception of certitude, relief, and security (Ha, 2004), thus boosting a feeling of confidence in the brand. Multiple positive brand experiences should also reinforce the feeling that the brand is sincere, consumer-centered, benevolent, and pursues positive goals.

Second, brand trust may promote an emotional-laden bond between consumers and 
brands. In psychology, the role of trust as an antecedent of emotional attachment is explained for three reasons. First, trust induces a positive emotional attachment because a trustworthy person is perceived as signaling care, concern, and connection. Burke and Stets (1999) show that trust in a partner is central to the subjective development of an emotionally based interpersonal connection. Second, the development of attachment depends on the satisfaction of one's needs (Hazan and Shaver, 1994) which relies on the existence of trust. A sense of attachment is based on expectations that key people will be available and responsive in times of need (Bowlby, 1982; Shaver et al., 2018). For instance, trust in an organization facilitates attachment through the satisfaction of employees' needs and interests, and the anticipation of favorable employment outcomes (Thau et al., 2007). Third, attachment to a partner depends on the way the partner is used as a source of safety and comfort (Fraley and Shaver, 2000). In the context of consumer-brand relationships, brand attachment is principally based on brand trust because it creates a comfort zone for consumers (Patwardhan and Balasubramanian, 2011; 2013). Thus, personal brand experiences that build trust enable the development of attachment (Park et al., 2006), as demonstrated both in retail where trust towards the brand is related to brand attachment (Frasquet et al., 2017; Vlachos et al., 2010), and in consumer goods where consumers' trust is related to attachment to brand Coca-Cola (Louis and Lombart, 2010). In summary, we suggest that multiple positive brand experiences are related to brand trust, which in turn is related to brand attachment. Based on these arguments, we propose:

H3: The positive link between brand experience and brand attachment is partially mediated by brand trust.

The Moderating Role of Income in the Relationship between Brand Experience, Brand Trust 
and Brand Attachment

The mediating role of brand trust in the relationship between brand experience and brand attachment should be weaker for individuals of higher income. Literature on human personality traits and career success suggests that agreeableness, of which trust is a component, is negatively related to income (Judge et al., 1999; Ng et al., 2005; Spurk and Abele, 2011). This is expressed by the fact that workers are required to be tough-minded and competition-oriented in order to climb the career ladder (Spurk and Abele, 2011). Thus, trust is felt in a lesser extent for individuals with higher income. Therefore, positively experiencing brands may boost a lesser degree of trust in the brand and it, in turn, promote a lesser degree of brand attachment for consumers of higher income.

Moreover, individuals of higher income are disposed to behave more selfishly (Dubois et al., 2015), which is contrary to expected reciprocity in a condition of trust (Rubin, 1975). The higher concern with one's own personal profit may limit the tendency to trust. Hence, higher income consumers could be less affected by the concept of trust, and its mediating role in the relationship between brand experience and brand attachment should be weaker than for other consumers. Based on these arguments, we propose:

H4: The mediating role of brand trust in the relationship between brand experience and brand attachment is weaker for high-income consumers than for low-income consumers.

The model is presented in Figure 1.

\section{Method}




\section{Data Collection and Sample}

We collected the data on a convenience sample of 334 individuals composed of both students $(38.4 \%)$ and graduates from a large University in Lima, Peru. We focused on the city of Lima because it is one of Latin America's most important financial centers ${ }^{1}$, home to many national and international companies selling strong brands. We used online questionnaires and a snowball method on Facebook during three weeks. The virtual snowball sampling method enabled expanding rapidly the sample size and accessing "hard to reach" individuals (Baltar and Brunet, 2012). The questionnaire was designed and self-administered through Google docs which helped ensure anonymity. The profile of respondents is shown in Table 1.

Table 1 about here

We exposed informants to a list of ten brands selected through a pre-test, and asked participants to choose the one with which they had a highly positive experience. If no brand from the list fulfilled this condition, participants had the option of proposing another brand. Then, study participants answered questions concerning brand experience, brand trust, and brand attachment, as well as demographics. The pre-test was conducted with 21 individuals (11 males, aged 20 to 30), and enabled selecting ten brands potentially generating positive experiences. Six brands were previously identified by a marketing professional because of their positive experiential offer and were submitted to the study participants who confirmed they generate positive experiences. Participants also proposed other brands favoring positive experience, and four brands generating a consensus were added, leading to a list of ten brands perceived as potential providers of positive experiences. The ten brands used in the main

\footnotetext{
${ }^{1} \mathrm{http}: / /$ www.infoplease.com/encyclopedia/world/lima-city-peru.html
} 
study included McDonald's and several local brands in different service categories: Play Land Park (leisure activity brand), Los Delfines (hotel brand), Pardos Chicken (restaurant), Wong, Tottus, and Ripley (retail), Cruz del Sur (travel), Banco de Credito del Peru (bank), and Cineplanet (movie theater).

\section{Measures}

Existing scales were adapted for each construct. Following the well-established backtranslation technique, a bilingual Spanish-English Peruvian first translated the questionnaire from English to Spanish which was then back-translated from Spanish to English by another bilingual Peruvian who lived in the United States for ten years. Four of the translated statements pertaining to brand experience were excluded due to difficulties of translation and understanding in Spanish.

Brand experience is measured through the scale of Brakus et al. (2009) composed of four dimensions: sensory, affective, intellectual, and behavioral. In addition, we included the social dimension of brand experience, eliminated in the purification process of Brakus et al. (2009). We wish to test whether this social dimension plays a role since the purification operated by Brakus et al. (2009) is linked to their data rather than resting on a theoretical perspective (Shamin and Butt, 2013). The dependent variable, brand attachment, is measured through the three dimensional scale (Affection, Passion, and Connection) of Thomson et al. (2005). The scale developed by Li et al. (2008) was employed to measure brand trust. All items were rated on a seven-point Likert agreement scale (from 1: "strongly disagree" to 7: “strongly agree"), see Table 2.

To test whether a common method bias is present in the data (Podsakoff et al., 2003), we conducted the Harman's one factor test. We identified the underlying factors through an 
un-rotated principal component analysis of the 30 items (12 items for brand experience, 9 items for brand trust, and 9 items for brand attachment). The analysis revealed the presence of 3 distinct factors with eigenvalues greater than 1 accounting for $63.1 \%$ of total variance. No single factor emerged from the analysis, and the first factor accounted for limited variance (24.1\%). Therefore, with no general factor identified, common method bias represents no threat for the data.

Table 2 about here

To estimate the measurement and structural models, we used Partial Least Square Structural Equation Modeling (PLS-SEM, Hair et al., 2016) through SmartPLS 3 software (Ringle et al., 2015). PLS-SEM analysis is justified because some sub-samples are relatively small (e.g. $n=100$ for the medium income group), and some variables (e.g. competence) do not follow a normal distribution (kurtosis > 1.5). PLS maintains the assumption of the quality of the model with non-normal data (Henseler et al., 2016) and analyzes complex models with scarce data (Rigdon, 2016). In addition, compared to covariance-based SEM, PLS is notably justified because our research entails theory development (Sarstedt et al., 2014), and a first effort to explore the indirect effect of brand experience on brand attachment through brand trust is made here. Likewise, the moderating effect of age and income allows for theory development. Second, PLS-SEM analysis allows for a predictive focus through the estimation of the path model relationships that maximize the $\mathrm{R}^{2}$ values of constructs (Hair et al., 2017). In this regard, we could identify the impact of brand experience on brand trust and of the latter on brand attachment. 


\section{Results}

Measurement Scales' Psychometric Properties

Reliability and convergent validity were respectively assessed by composite reliability (CR) and average variance extracted (AVE), both suggested by Fornell and Larcker (1981).

Discriminant validity was assessed through the heterotrait-monotrait ratio (HTMT) because of its superior performance compared to more traditional methods (Henseler et al., 2015), and standardized loadings $(\lambda)$ were used to assess indicator reliability (Hair et al., 2011). The thresholds for CR, AVE, and $\lambda$ are 0.7, 0.5, and 0.7, respectively, and for the HTMT criterion, we use the 0.9 threshold level (Henseler et al., 2015).

The measurement model includes three multidimensional constructs: brand experience, brand trust, and brand attachment. Table 3 indicates that all indicator loadings on their corresponding constructs are higher than 0.7. CR and AVE of all the constructs are higher than 0.7 and 0.5 respectively. Discriminant validity is established since all HTMT criteria are below 0.9 (Table 4). Therefore, the measurement model possesses clear evidence of reliability, convergent validity and discriminant validity.

Table 3 and Table 4 about here

\section{Direct and Indirect Effects}

sepi: $W e$ tested the hypotheses using 5000 bootstraps resamples (Table 5). The results show that brand experience has a positive direct effect on brand attachment $(\gamma=0.550, p<0.01)$ in support of H1. In addition, brand experience has a positive effect on brand trust, which in turn has a positive effect on brand attachment. In order to test the partial mediating hypothesis $(\mathrm{H} 3$ : 
mediation of brand trust between brand experience and brand attachment), we examine the indirect effect of brand experience on brand attachment through brand trust. The product of the coefficients using the bootstrapping resampling method (Nitzl et al., 2016) demonstrates the significant partial mediating role of brand trust $(\gamma=0.180, p<0.01)$, in support of H3. It appears that the direct effect of brand experience on brand attachment is stronger than the indirect effect through brand trust ( $\gamma=0.550$ and $\gamma=0.180$ respectively), and that brand experience through both direct and indirect effects explains the formation of brand attachment $\left(\mathrm{R}^{2}=63.2 \%\right)$. Brand experience also explains brand trust $\left(\mathrm{R}^{2}=24.5 \%\right)$ justifying the inclusion of brand trust in the model.

Table 5 about here

\section{Moderation by Age}

We contrast two age groups of similar size: younger consumers (18 to 25 years old, $48.2 \%$ of study participants) and older consumers (over 25 years old), and conducted a multigroup analysis which first requires to establish measurement invariance (Henseler et al., 2016; Sarstedt et al., 2011). We tested the measurement invariance of composites (Henseler et al., 2016), which implies configural invariance, compositional invariance, and equal means and variances for the groups. Table 6 indicates full measurement invariance between the groups.

Table 6 about here 
We separately bootstrapped parameters for each group to verify a probable difference between these parameters (Henseler, 2007). Compared with the parametric approach of Keil et al. (2000), the Henseler's bootstrap method does not need any distributional assumptions, thus being compatible with the PLS-SEM method. The results of the multigroup analysis indicate a significant difference between younger and older consumers in the effect of brand experience on brand attachment $(\Delta \gamma=0.145, \mathrm{p}<0.05)$, with a stronger link between the two concepts for younger consumers, in support of $\mathrm{H} 2$ (Table 7).

Table 7 about here

\section{Moderation by Income}

We composed three income groups of equal size (low, medium, high income groups) and first controlled for measurement invariance through single pairwise comparisons. Full measurement invariance between groups 1 and 2 is established for all constructs (except for one item) (Appendix 1). Full and partial measurement invariance of the other group comparisons is established for all constructs (Appendix 2 and 3). Partial measurement invariance is a minimum requirement for interpreting differences between groups (Henseler $e t$ al., 2016).

The results of single pairwise comparisons indicate no differences between consumers of low and medium income) in the indirect effect of brand experience on brand attachment $(\Delta \gamma=0.021, p>0.05$, Table 8). There are however significant differences between consumers of low and high income $(\Delta \gamma=0.192, \mathrm{p}<0.01)$, and between consumers of medium and high income $(\Delta \gamma=0.171, \mathrm{p}<0.01)$. The link between brand experience and brand attachment (mediated by brand trust) is weaker for consumers of high income in support of H4 (Table 8). 


\section{Analysis by brand type}

The results we obtained on pooled data (10 brands) may vary across brand types. To determine the robustness of the model to variations among specific groups of brands, we clustered brands into utilitarian and hedonic brands, and tested our model across the two brand types.

Although all brands were chosen by study participants because they offer great experience to consumers, the main value for which they are consumed varies. For instance, Banco de Credito is principally used for its utilitarian purpose such as service of transactional accounts. On the other hand, Play Land Park's main purpose is hedonic because of the entertainment it provides, and the experiential aspect of this brand is the essence of its offer. The data was split into two groups of brands differentiated by their main purpose: brands mainly consumed because of their hedonic purpose (Los Delfines, Play Land Park, Wong, Pardos Chicken, Ripley, and Cineplanet) and brands with a more utilitarian purpose (Banco de Credito, Cruz del Sur, McDonald's, and Tottus).

In order to separate these two types of brands based on data collected, we conducted a non-hierarchical k-means cluster analysis based on the mean scores for the five experiential dimensions. This cluster analysis method is justified since an exact number of clusters was expected. Table 9 shows the difference of mean scores between brands with a more hedonic purpose (Cluster I) and brands with a more utilitarian purpose (Cluster II) on each experiential dimension. Brands with a more hedonic purpose exhibit a higher level of experience than 
brands with a more utilitarian purpose on four of the five dimensions (the ANOVA demonstrates significant differences except for the intellectual dimension). Cluster I (172 respondents) contains Los Delfines, Play Land Park, Ripley, Wong and Pardos Chicken, whereas Cluster II (135 respondents) contains Cineplanet, Banco de Credito, Tottus, Cruz del Sur and McDonald's. These two types of brands were analyzed separately to re-test our hypotheses within both groups.

Table 9 about here

Measurement invariance was established through the measurement invariance of composites (Henseler et al., 2016), and results indicate full measurement invariance between the two groups of brands (Appendix 4).

After bootstrapping parameters (Table 10), results indicate that hypotheses $\mathrm{H} 1$ and $\mathrm{H} 3$ are supported for each group of brands. For brands with a more hedonic purpose, brand experience has a direct effect on brand attachment $(\gamma=0.615, \mathrm{p}<0.001$, in support of H1) and indirect effect on brand attachment $(\gamma=0.365 * 0.297=0.108, \mathrm{p}<0.001$, in support of H3). Similarly, brand attachment is influenced by brand experience directly $(\gamma=0.440, p<0.001$, in support of H1) and indirectly $(\gamma=0.635 * 0.445=0.282, \mathrm{p}<0.001$, in support of H3) for brands with a more utilitarian purpose. Also, the total effect of brand experience on brand attachment for hedonic brands is 0.723 and 0.722 for utilitarian brands. Therefore, results indicate that the total effect is the same for both brand types but via different paths. In summary, the robustness of the model is verified for both hedonic and utilitarian brands.

In addition, the results of a multigroup analysis indicate a significant difference between brands with either a utilitarian or a hedonic purpose in the effect of brand experience 
on brand attachment $(\Delta \gamma=0.166, \mathrm{p}<0.05)$, with a stronger link between the two concepts for brands with a hedonic purpose. There is a significant difference between brand types in the effect of brand experience on brand trust $(\Delta \gamma=0.270, \mathrm{p}<0.01)$, with a stronger link between the two concepts for brands with a utilitarian purpose. There is no significant difference between the two groups in the effect of brand trust on brand attachment (Table 10).

Table 10 about here

A synthesis of main results is presented in Figure 2.

\section{Discussion and Conclusion}

Conceptual and empirical evidence support our hypotheses. First, contrary to Brakus et al. (2009), we demonstrate that the social aspect of brand experience should be considered as a dimension of the concept, based on psychometric properties. These results are in line with the work of Shamin and Butt (2013) who also validate the social dimension of brand experience on the mobile phone category. We extend this result on other brand categories. In addition, contrary to Huang et al. (2015) who considered the social dimension as a consequence of brand experience, we show that the social dimension converges with other dimensions of brand experience, forming a second-order construct.

Second, structural analysis showed that brand experience has a positive direct effect on brand attachment both on pooled data and within product types. Evoking positive and multiple internal responses while experiencing brands positively influences the emotional bond between consumers and brands. This confirms the results of the exploratory research 
conducted by Japutra et al. (2014b) who established that English consumers manifest their attachment to Fatface or Xbox because they enjoyed their experience. Our result is also in line with the results of Dolbec and Chebat (2013) whereby North American female consumers attach more to fashion brands that provide a strong experience, and of Kang et al. (2016) who demonstrate that Malaysian travelers attach more to hotel brands when they lived strong positive brand experiences. Therefore, our study generalizes past research to other brand categories, and to Latin American consumers.

Third, in the relationship between brand experience and brand attachment, this study demonstrates the partially mediating role of brand trust. Successful experiences with a brand positively influence the beliefs that the brand delivers quality products or services, and that it takes care of its consumers with integrity and benevolence (Francisco-Maffezzolli et al., 2014; Khan and Fatma, 2017; Shamim and Butt, 2013). Trust, in turn, positively influences consumers' attachment to the brand because individuals will attach more to brands that fulfill their promise, are benevolent, and provide security and confidence. Unlike past research that proposed brand attachment as an antecedent of brand trust (Belaid and Behai, 2011; CorreiaLoureiro et al., 2012; Kang et al., 2016), we present a clear theoretical justification of the direction of the relationship from brand trust to brand attachment based on the field of social psychology.

\section{Theoretical contributions}

This research thus provides a new perspective on the consequences of positive brand experience. Contrasting with past research that principally focuses on satisfaction (Brakus et al., 2009; Khan et al., 2016), brand equity (Lin, 2015; Shamim and Butt, 2013), or word of mouth (Klein et al., 2016; Ngo et al., 2016) as consequences of brand experience, we consider a more emotional consequence, i.e. brand attachment which is an expression of affection, 
passion, and connection, and which was linked to valuable behavioral consequences such as brand loyalty and willingness to pay a price premium (Thomson et al., 2005). We show how a more cognitive aspect (brand trust) may be impacted by positive brand experience, and that brand trust, in turn, favors brand attachment. Therefore, brand experience favors brand attachment directly through an emotional route and indirectly through brand trust, a more cognitive route.

Concerning the moderating role of individual variables (age and income), multi-group analyses revealed significant differences between younger consumers and older consumers in the direct effect of brand experience on brand attachment. The positive effect of brand experience on brand attachment is stronger for younger consumers. This indicates that younger consumers are more likely to create an emotional bond with brands when multiple and positive internal responses are evoked through brand experience. These results are consistent with Loureiro and Roschk (2013) who showed that age moderates the relationship between positive emotions and loyalty in store brands. This relationship was significant for younger consumers but not for older consumers, and was explained by the fact that older consumers show higher emotional control and maturity in their emotional states. Beyond this interpretation, we argue that age influences the way individuals experience affect. Older individuals have a tendency to adapt more easily to emotional events because of repeated exposure (Diener et al., 1985; Larsen and Diener, 1987). Second, age influences the behavior displayed to receive external stimulation. Younger individuals search for stimuli that produce excitement and emotions because they are more change-oriented and carry less conservative propensities (Zuckerman, 1979). Recent work (McKay-Nesbitt et al., 2011); Sudbury-Riley and Edgar, 2017) confirm that emotional appeal is stronger for younger adults than for older adults. Therefore, our results concerning the influence of age are in line with recent results and further contribute to the understanding of consumer-brand relationships. In addition, it is relevant to notice that 
although younger consumers attach more to brands that provide a strong positive experience, they are also less likely to remain attached to the same brands (Lambert-Pandraud and Laurent, 2010).

Concerning income, the indirect effect of brand experience on brand attachment mediated by brand trust is positive across the three-income groups (low, medium and high). However, this indirect effect is smaller for consumers of higher income compared to the two other income groups. This indicates that for consumers of low and medium income, brand trust is more likely to create a cognitive path when multiple and positive internal responses stimulated by brand experience form an emotional bond. The fact brand trust plays a less important role for high-income consumers may be explained by the fact that such individuals are more likely to behave selfishly (Dubois et al., 2015), and are required to be tough-minded and competition-oriented to progress up the career path (Spurk and Abele, 2011) leading to a general tendency to distrust. Our results are in line with the results of Homburg and Giering (2000) in the context of consumer-brand relationships, and in which the relationship between satisfaction and brand loyalty is weaker for consumers with high income. They are also consistent with those of Mishra (2014), in which the more cognitive path (i.e. utilitarian) of the influence of perceived value on satisfaction is higher for low-income consumers. Since brand experience, brand trust, and brand attachment are important predictors of consumer satisfaction and brand loyalty (Brakus et al., 2009; Chaudhuri and Holbrook, 2001), our results extend the influence of income on consumer-brand relationships.

In summary, we establish an alternative chain of effects from brand experience to brand attachment and identify one partial mediator (brand trust) and two moderating variables neglected in previous research.

The robustness of the results is demonstrated across product types since hypotheses 
linking brand experience to brand trust and to brand attachment are supported for both utilitarian and hedonic products. In addition, brand experience is more strongly linked to brand attachment for brands with a hedonic purpose and more strongly linked to brand trust for utilitarian brands. In other words, hedonic brands perceived as more experiential in terms of sensory, affective, behavioral and social responses are more likely to stimulate directly consumers' attachment. In our data, Los Delfines (luxury hotel), Play Land Park (entertainment), Ripley (fashion retail), or Pardos Chicken (casual dining) present a higher level of brand attachment than Banco de Crédito (banking), Cruz del Sur (transport), Tottus (grocery store), because they are more experiential and mainly have a hedonic purpose.

Concerning utilitarian brands, we demonstrate that the relationship between brand experience and brand trust is stronger, and that the direct relationship between brand experience and brand attachment is weaker than for hedonic brands. This results is not surprising since the evaluation of brand trust is mainly characterized by the use of cognitive cues which is more the case for brands with a main utilitarian purpose than for brands with a hedonic purpose.

However, while the paths from brand experience to brand attachment are different across the two brand types, the total effect of brand experience on brand attachment is the same (.723 for hedonic brands and .722 for utilitarian brands). This important result provides evidence that the concept of brand experience is fundamental to brand attachment independent of brand type. This contrasts with past research that puts forward the concept of "experiential brands" which are contrasted with "utilitarian brands" (e.g. Delgados-Ballester and FernandezSabiote, 2015). Even if we confirm that utilitarian brands favor on average less brand experience than hedonic brands, brands with a main utilitarian purpose can also be perceived as experiential through a direct (e.g. store experience) or indirect (e.g. advertising) interaction with consumers. Moreover, stimulating brand experience with utilitarian brands has the same 
overall effect on brand attachment than hedonic ones, even though paths to attachment vary.

\section{Managerial implications}

The findings of this study have implications for brands that need to strengthen their relationship with consumers, and more specifically for brands seeking to create or improve an emotional bond with consumers. An experiential positioning strategy may help companies increase attachment to their brands both through a direct effect and through the enhancement of brand trust. Reinforcing brand trust in itself will favor brand attachment. Facilitating the interaction of the brand with consumers in order to stimulate multiple and internal responses linked to different dimensions of the experience (sensorial, emotional, intellectual, behavioral, and social) will facilitate attachment. For instance, companies may create spaces for brand exposure (e.g. brand museums, factory visits) favoring a direct proximity with the brand and an understanding of what the brand stands for. Brands might also improve their stores, Internet sites, and services to stimulate contentment and gratification. This will lead to positive memories thus creating attachment to the brand. Creating positive consumer experiences in touchpoints other than mere product or service consumption (e.g. witnessing all brand aspects such as the choice of ingredients or raw material, production processes, packaging, employees, and organization during company visits) may help consumers appreciate the positive properties of brands and their effort to produce the best quality, thus influencing attachment through trust. On another hand, brand attachment may be directly stimulated through unusual experiences linked to brands such as creating events or institutions sponsored or fully financed by brands. Famous examples are the Cartier foundation for contemporary arts in Paris, the Frank Gehry designed art museum and cultural center Louis Vuitton sponsored by LVMH (Louis Vuitton Moët Hennessy) or art museums created by 
Prada or Max Mara, all occasions to develop indirect brand experiences favoring brand attachment.

\section{Limitations and future research}

This study has some limitations that could be overcome in future research. First, data were collected in one specific setting, that of Peru, on both international and Peruvian brands. Although Peru is adopting a western style (especially the younger population), it still has specific cultural aspects that may have influenced results, just like any other specific country in which data are collected. One the one hand, retesting the direct relationship between brand experience and brand attachment in a Peruvian context and confirming previous findings established in Western countries is of interest. On the other hand, the novel contributions linked to the introduction of a mediating variable (trust) and of two moderators (age and income) needs further testing in other economic or cultural contexts.

Second, the cross-sectional nature of our research design forces some limitations regarding the sequence of the constructs. This type of design does not enable to prove causality (Bagozzi and Yi, 2011; Bollen and Pearl, 2013). Although the existence of a path from brand experience to brand attachment is theoretically justified and supported by the data, an experimental design could be used to verify cause to effect inferences. For instance, in order to show the causality of brand trust on brand attachment, future research should manipulate the competence and benevolence of brands and test if this has an effect on brand attachment.

Third, we considered two moderating variables (age and income). Other variables may well be considered for themselves or in interaction with age and income. A potential important moderator of the relationships we examined (between brand experience, brand trust 
and brand attachment) is gender. It is established that women are more open to experience (Costa et al., 2001) and are more emotionally dependent (Alonso-Arbiol et al., 2002). Therefore, the effect of brand experience on brand attachment may be stronger for women. Also, women appear to be more trusting than men (Feingold, 1994; Meyers-Levy and Loken, 2015), and women believe more in the honesty and benevolence of other individuals because men focus more on instrumentality whereas women are more socially oriented (Buchan et al., 2008; Cross and Madson, 1997). Therefore, because positive brand experience involves interactions between consumers and brands often with a social component, trust might play a bigger role for women in the indirect experience-attachment relationship. In addition, since women are more aware of the feelings of others and more concerned with interdependences rendering relationships more important (Costa et al., 2001), trust might be more relevant for women. For instance, the influence of trust on the desire to maintain a relationship with internet service providers is stronger for women (Sanchez-Franco et al., 2009). Finally, future research should focus on the effect of each brand experience type (i.e. sensorial, emotional, intellectual, behavioral, and social) on brand attachment. How the interactions of these experiences could differently impact the direct and indirect relationships to brand attachment would be an important contribution both at the academic and at the managerial levels.

Fourth, following the arguments proposed above, the slight overrepresentation of men $(62 \%)$ in our sample might have mitigated the effect of brand experience on brand trust and the latter on brand attachment. Future research should analyze samples equally represented in terms of gender in order to avoid any potential bias or formally contrast results across genders.

Fifth, despite the fact that the Harman' one factor test is the most common technique used by researchers for identifying common method variance, it suffers some limitations (Hulland et al., 2017, Kemery and Dunlap, 1986). Future research should use supplemental 
techniques such as the marker variable technique (Lindell and Whitney, 2001).

Sixth, the reduced representativeness and the selection bias of the snowball sampling method may limit the generalizability of results (Baltar and Brunet, 2012). Future research should consider probability sampling methods to generate more representative samples or make ex-post adjustments to the snowball sampling method in order to compensate for unequal selection probabilities or non-coverage (Sarstedt et al., 2018).

Seventh, incorporating an experiential perspective to the study of negative brand relationships (i.e. brand hate (Zarantonello et al., 2016), brand avoidance (Lee et al., 2009)) should be encouraged. Fournier and Alvarez (2013) express that negative relationships, compared to positive ones, are more problematic because negative outcomes are more memorable, more diagnostic and evoke more important psychological response. On the basis of an experiential perspective, future research should study how negative sensory, emotional, intellectual, behavioral, and social brand experience influence negative consumer/brand relationships such as brand hate or brand avoidance. Furthermore, how a negative experience in one dimension could influence the global evaluation of brand experience or interact with a positive experience linked to other dimensions may be an interesting area for future research. For instance, a negative social experience could diminish or even reverse the positive sensory, emotional, intellectual, behavioral or global experience with a brand which in turn would negatively influence brand trust or brand attachment. 


\section{References}

Accenture (2015), “Improving Customer Experience Is Top Business Priority for Companies Pursuing Digital Transformation, According to Accenture Study," news release, (October 27), [available at https://newsroom.accenture.com/news/improving- customerexperience-is-top-business-priority-for-companies-pursuing-digital-transformationaccording-to-accenture-study.htm].

Albert, N., Merunka, D. and Valette-Florence, P. (2013), "Brand passion: antecedents and consequences", Journal of Business Research, Vol. 66 No. 7, pp. 904-909.

Alloza, A. (2008), "Brand engagement and brand experience at BBVA, the transformation of a 150-year-old company", Corporate Reputation Review, Vol. 11 No. 4, pp. 371-379.

Alonso-Arbiol, I., Shaver, P.R. and Yárnoz, S. (2002), "Insecure attachment, gender roles, and interpersonal dependency in the Basque Country", Personal Relationships, Vol. 9 No. 4, pp. 479-490.

Bagozzi, R.P. and Yi, Y. (2012), "Specification, evaluation, and interpretation of structural equation models", Journal of the Academy of Marketing Science, Vol. 40 No. 1, pp. 834.

Bauer, H.H, Heinrich, D. and Marin, I. (2007), "How to create high emotional consumerbrand relationships? The causalities of brand passion", Proceedings of the Australian and New Zealand Marketing Academy Conference, University of Otago; 2007, pp. 2189-2198.

Baldwin, M.W., Keelan, J.P.R., Fehr, B., Enns, V. and Koh-Rangarajoo, E. (1996), "Socialcognitive conceptualization of attachment working models: availability and accessibility effects", Journal of Personality and Social Psychology, Vol. 71 No. 1, pp. 94-109.

Baltar, F. and Brunet, I. (2012), "Social research 2.0: Virtual snowball sampling method using Facebook", Internet Research, Vol. 22 No. 1, pp. 57-74.

Beckman, E., Kumar, A. and Kim, Y.K. (2013), "The impact of brand experience on downtown success", Journal of Travel Research, Vol. 52 No. 5, pp. 646-658.

Belaid, S. and Behi, A.T. (2011), "The role of attachment in building consumer-brand relationships: an empirical investigation in the utilitarian consumption context", Journal of Product \& Brand Management, Vol. 20 No. 1, pp. 37-47.

Bidmon, S. (2017), "How does attachment style influence the brand attachment-brand trust and brand loyalty chain in adolescents?", International Journal of Advertising, Vol. 36 No. 1, pp. 164-189.

Birditt, K.S. and Fingerman, K.L. (2003), “Age and gender differences in adults' descriptions of emotional reactions to interpersonal problems", The Journals of Gerontology Series B: Psychological Sciences and Social Sciences, Vol. 58 No. 4, pp. 237-245.

Bollen, K.A. and Pearl, J. (2013), "Eight myths about causality and structural equation models", in Handbook of causal analysis for social research (pp. 301-328). Springer, Dordrecht.

Bowlby, J. (1979), The making and breaking of affectional bonds. London: Tavistock.

Brislin, R.W. (1970), "Back-translation for cross-cultural research", Journal of CrossCultural Psychology, Vol. 1 No. 3, pp. 185-216.

Brakus, J., Schmitt, B. and Zarantonello, L. (2009), "Brand Experience: what is It? How is it measured? Does it affect loyalty?", Journal of Marketing, Vol. 73 No. 3, pp. 52-68.

Buchan, N.R., Croson, R.T. and Solnick, S. (2008), "Trust and gender: an examination of 
behavior and beliefs in the Investment Game", Journal of Economic Behavior \& Organization, Vol. 68 No. 3, pp. 466-476.

Burke, P.J. and Stets, J.E. (1999), "Trust and commitment through self-verification", Social Psychology Quarterly, Vol. 62 No. 4, pp. 347-366.

Cardinale, S., Nguyen, B. and Melewar, T.C. (2016), "Place-based brand experience, place attachment and loyalty", Marketing Intelligence \& Planning, Vol. 34 No. 3, pp. 302317.

Carstensen, L.L. (1992), "Social and emotional patterns in adulthood: support for socioemotional selectivity theory", Psychology and Aging, Vol. 7 No. 3, pp. 331-338.

Chandler, J.D. and Lusch, R.F. (2015), "Service systems: a broadened framework and research agenda on value propositions, engagement, and service experience", Journal of Service Research, Vol. 18 No. 1, Vol. 6-22.

Chaudhuri, A. and Holbrook, M.B. (2001), "The chain of effects from brand trust and brand affect to brand performance: the role of brand loyalty", Journal of Marketing, Vol. 65 No. 2, pp. 81-93.

Correia-Loureiro, S.M., Ruediger, K.H. and Demetris, V. (2012), "Brand emotional connection and loyalty", Journal of Brand Management, Vol. 20 No. 1, pp. 13-27.

Costa, P.T. and McCrae, R.R. (1986), "Cross-sectional studies of personality in a national sample: I. Development and validation of survey measures", Psychology and Aging, Vol. 1 No. 2, pp. 140-143.

Costa Jr., P.T., McCrae, R.R., Zonderman, A.B., Barbano, H.E., Lebowitz, B. and Larson, D.M. (1986), "Cross-sectional studies of personality in a national sample: II. Stability in neuroticism, extraversion, and openness", Psychology and Aging, Vol. 1 No. 2, 144149.

Costa Jr., P.T., Terracciano, A. and McCrae, R.R. (2001), "Gender differences in personality traits across cultures: robust and surprising findings", Journal of Personality and Social Psychology, Vol. 81 No. 2, pp. 322-331.

Cross, S.E. and Madson, L. (1997), "Models of the self: self-construals and gender", Psychological bulletin, Vol. 122 No. 1, 5-37.

Delgado-Ballester, E. and Fernandez Sabiote, E. (2015), "Brand experimental value versus brand functional value: which matters more for the brand?", European Journal of Marketing, Vol. 49 No. 11/12, 1857-1879.

Delgado-Ballester, E. and Munuera-Aleman, J.L. (2001), "Brand trust in the context of consumer loyalty", European Journal of Marketing, Vol. 35 No. 11/12, pp. 1238-1258.

Diener, E., Sandvik, E. and Larsen, R.J. (1985), “Age and sex effects for emotional intensity”, Developmental Psychology, Vol. 21 No. 3, pp. 542-546.

Ding, C.G. and Tseng, T.H. (2015), "On the relationships among brand experience, hedonic emotions, and brand equity", European Journal of Marketing, Vol. 49 No. 7/8, 9941015.

Dolbec, P.Y. and Chebat, J.C. (2013), "The impact of a flagship vs. a brand store on brand attitude, brand attachment and brand equity", Journal of Retailing, Vol. 89 No. 4, pp. 460-466.

Doney, P.M. and Cannon, J.P. (1997), “An examination of the nature of trust in buyer-seller relationships", Journal of Marketing, Vol. 61 No. 2, pp. 35-51.

Drolet, A., Williams, P. and Lau-Gesk, L. (2007), "Age-related differences in responses to affective vs. rational ads for hedonic vs. utilitarian products", Marketing Letters, Vol. 18 No. 4, pp. 211-221. 
Dubois, D., Rucker, D.D. and Galinsky, A.D. (2015), "Social class, power, and selfishness: When and why upper and lower class individuals behave unethically", Journal of Personality and Social Psychology, Vol. 108 No. 3, pp. 436-449.

Dunn, L. and Hoegg, J. (2014), "The impact of fear on emotional brand attachment", Journal of Consumer Research, Vol. 41 No. 1, pp. 152-168.

Escalas, J.E. and Bettman, J.R. (2000), "Using narratives and autobiographical memories to discern motives", The Why of Consumption: Perspectives on Consumer Motives, Goals, and Desires, pp. 237-258.

Escalas, J.E. and Bettman, J.R. (2003), "You are what they eat: the influence of reference groups on consumers' connections to brands", Journal of Consumer Psychology, Vol. 13 No. 3, pp. 339-348.

Esch, F.R., Langner, T., Schmitt, B.H. and Geus, P. (2006), “Are brands forever? How brand knowledge and relationships affect current and future purchases", Journal of Product \& Brand Management, Vol. 15 No. 2, pp. 98-105.

Fedorikhin, A., Park, C.W. and Thomson, M. (2008), "Beyond fit and attitude: the effect of emotional attachment on consumer responses to brand extensions", Journal of Consumer Psychology, Vol. 18 No. 4, pp. 281-291.

Feingold, A. (1994), "Gender differences in personality: a meta-analysis", Psychological Bulletin, Vol. 116 No. 3, pp. 429-456.

Forbes (2016), "How to create attachment to your brand with customer experience", news release (September 6), [https://www.forbes.com/sites/danielnewman/2016/09/06/howto-create-attachment-to-your-brand-with-customer-experience/\#316781c47296]

Fornell, C. and Larcker, D.F. (1981), "Structural equation models with unobservable variables and measurement error: algebra and statistics", Journal of Marketing Research, Vol. 18 No. 3, pp. 382-388.

Fortune (2017), fortune.com/2017/03/30/apple-intimate-brand/

Fournier, S. and Alvarez, C. (2013), "Relating badly to brands", Journal of Consumer Psychology, Vol. 23 No. 2, pp. 253-264.

Fraley, R.C. and Shaver, P.R. (2000), "Adult romantic attachment: theoretical developments, emerging controversies, and unanswered questions", Review of General Psychology, Vol. 4 No. 2, pp. 132-154.

Francisco-Maffezzolli, E.C., Semprebon, E. and Prado, P.H.M. (2014), "Construing loyalty through brand experience: the mediating role of brand relationship quality", Journal of Brand Management, Vol. 21 No. 5, pp. 446-458.

Frasquet, M., Mollá-Descals, A. and Ruiz-Molina, M.E. (2017), "Understanding loyalty in multichannel retailing: the role of brand trust and brand attachment", International Journal of Retail \& Distribution Management, Vol. 45 No. 6, pp. 608-625.

Gabisch, J.A. (2011), "Virtual world brand experience and its impact on real world purchasing behavior", Journal of Brand Management, Vol. 19 No. 1, pp. 18-32.

Gaston-Breton, C. and Raghubir, P. (2013), "Opposing effects of sociodemographic variables on price knowledge", Marketing Letters, Vol. 24 No. 1, pp. 29-42.

Gentile, C., Spiller, N. and Noci, G. (2007), "How to sustain the customer experience: an overview of experience components that co-create value with the customer", European Management Journal, Vol. 25 No. 5, pp. 395-410.

Gross, J.J., Carstensen, L.L., Pasupathi, M., Tsai, J., Götestam-Skorpen, C. and Hsu, A.Y. (1997), "Emotion and aging: experience, expression, and control", Psychology and Aging, Vol. 12 No. 4, pp. 590-599.

Ha, H.Y. (2004), "Factors influencing consumer perceptions of brand trust online", Journal of Product \& Brand Management, Vol. 13 No. 5, pp. 329-342. 
Hair, J.F., Ringle, C.M. and Sarstedt, M. (2011), "PLS-SEM: Indeed a silver bullet", The Journal of Marketing Theory and Practice, Vol. 19 No. 2, pp. 139-152.

Hair, J.F., Hult, G.T.M., Ringle, C.M. and Sarstedt, M. (2017), A primer on partial least squares structural equation modeling (PLS-SEM) ( $2^{\text {nd }}$ ed. $)$. Los Angeles, CA: Sage Publications.

Hazan, C. and Shaver, P.R. (1987), "Romantic love conceptualized as an attachment process", Journal of Personality and Social Psychology, Vol. 52 No. 3, pp. 511-524.

Hazan, C. and Shaver, P.R. (1994), "Attachment as an organizational framework for research on close relationships", Psychological Inquiry, Vol. 5, No. 1, pp. 1-22.

Hegner, S.M., Fetscherin, M. and van Delzen, M. (2017), "Determinants and outcomes of brand hate", Journal of Product \& Brand Management, Vol. 26 No. 1, pp. 13-25.

Helkkula, A. (2011), "Characterising the concept of service experience", Journal of Service Management, Vol. 22 No. 3, pp. 367-389.

Henseler, J. (2007), "A new and simple approach to multi-group analysis in partial least squares path modeling", in H. Martens \& T. Næs (ed.), Causalities explored by indirect observation, Proceedings of the 5th international symposium on PLS and related methods (PLS'07), Oslo, pp. 104-107.

Henseler, J., Ringle, C.M. and Sarstedt, M. (2015), "A new criterion for assessing discriminant validity in Variance-based Structural Equation Modeling", Journal of the Academy of Marketing Science, Vol. 43 No. 1, pp. 115-135.

Henseler, J., Ringle, C.M. and Sarstedt, M. (2016), "Testing measurement invariance of composites using partial least squares", International Marketing Review, Vol. 33 No. 3, pp. 405-431.

Henseler, J., Ringle, C.M. and Sinkovics, R.R. (2009), "The use of partial least squares path modeling in international marketing", in R.R. Sinkovics and P.N. Ghauri (Eds.), Vol. 20. Advances in International Marketing, pp. 277-320. England: Emerald: Bingley.

Holbrook, M.B. and Hirschman, E.C. (1982), "The experiential aspects of consumption: consumer fantasies, feelings, and fun", Journal of Consumer Research, Vol. 9 No. 2 , $132-140$.

Homburg, C. and Giering, A. (2001), "Personal characteristics as moderators of the relationship between customer satisfaction and loyalty-an empirical analysis", Psychology \& Marketing, Vol. 18 No. 1, pp. 43-66.

Homburg, C., Jozić, D. and Kuehnl, C. (2017), "Customer experience management: toward implementing an evolving marketing concept", Journal of the Academy of Marketing Science, Vol. 45 No. 3, pp. 377-401.

Huang, X., Huang, Z. and Wyer Jr, R.S. (2017), "The influence of social crowding on brand attachment", Journal of Consumer Research, Vol. 44 No. 5, 1068-1084.

Huang, R., Lee, S.H., Kim, H. and Evans, L. (2015), "The impact of brand experiences on brand resonance in multi-channel fashion retailing", Journal of Research in Interactive Marketing, Vol. 9 No. 2, pp. 129-147.

Hulland, J., Baumgartner, H. and Smith, K.M. (2018), "Marketing survey research best practices: evidence and recommendations from a review of JAMS articles", Journal of the Academy of Marketing Science, Vol. 46 No. 1, pp. 92-108.

Jahn, S., Gaus, H. and Kiessling, T. (2012), "Trust, commitment, and older women: Exploring brand attachment differences in the elderly segment", Psychology \& Marketing, Vol. 29 No. 6, pp. 445-457.

Jain, R., Aagja, J. and Bagdare, S. (2017), "Customer experience-A review and research agenda", Journal of Service Theory and Practice, Vol. 27 No. 3, pp. 642-662.

Japutra, A., Ekinci, Y., Simkin, L. and Nguyen, B. (2014a), "The dark side of brand attachment: a conceptual framework of brand attachment's detrimental outcomes", The 
Marketing Review, Vol. 14 No. 3, pp. 245-264.

Japutra, A., Ekinci, Y. and Simkin, L. (2014b), "Exploring brand attachment, its determinants and outcomes", Journal of Strategic Marketing, Vol. 22 No. 7, pp. 616-630.

Japutra, A., Ekinci, Y. and Simkin, L. (2016), "Tie the knot: building stronger consumers' attachment toward a brand", Journal of Strategic Marketing, 1-18. http://dx.doi.org/ 10.1080/0965254X.2016.1195862.

Japutra, A., Ekinci, Y. and Simkin, L. (2017), "Self-congruence, brand attachment and compulsive buying", Journal of Business Research. doi: 10.1016/j.jbusres.2017.08.024

Japutra, A. and Molinillo, S. (2017), "Responsible and active brand personality: on the relationships with brand experience and key relationship constructs", Journal of Business Research. http://dx.doi.org/10.1016/j.jbusres.2017.08.027

Japutra, A., Ekinci, Y. and Simkin, L. (2018a), "Positive and negative behaviours resulting from brand attachment: the moderating effects of attachment styles", European Journal of Marketing, Vol. 52 No. 5/6, pp. 1185-1202.

Japutra, A., Ekinci, Y., Simkin, L. and Nguyen, B. (2018b), "The role of ideal selfcongruence and brand attachment in consumers' negative behaviour: Compulsive buying and external trash-talking", European Journal of Marketing, Vol. 52 No. 3/4, pp. 683-701.

Judge, T.A., Higgins, C.A., Thoresen, C.J. and Barrick, M.R. (1999), "The big five personality traits, general mental ability, and career success across the life span", Personnel Psychology, Vol. 52 No. 3, pp. 621-652.

Kang, J., Manthiou, A., Sumarjan, N. and Tang, L. (2016), "An Investigation of Brand Experience on Brand Attachment, Knowledge, and Trust in the Lodging Industry", Journal of Hospitality Marketing \& Management, Vol. 26 No. 1, pp. 1-22.

Keil, M., Tan, B.C., Wei, K.K., Saarinen, T., Tuunainen, V. and Wassenaar A. (2000), "A Cross-Cultural Study on Escalation of Commitment Behavior in Software Projects", MIS Quarterly, Vol. 24 No. 2, pp. 299-325.

Kemery, E.R. and Dunlap, W.P. (1986), "Partialling factor scores does not control method variance: A reply to Podsakoff and Todor", Journal of Management, Vol. 12 No. 4, pp. 525-530.

Kessler, E.M. and Staudinger, U.M. (2009), "Affective experience in adulthood and old age: The role of affective arousal and perceived affect regulation", Psychology and Aging, Vol. 24 No. 2, pp. 349-362.

Khan, I., Rahman, Z. and Fatma, M. (2016a), "The role of customer brand engagement and brand experience in online banking", International Journal of Bank Marketing, Vol. 34 No. 7, pp. 1025-1041.

Khan, I., Rahman, Z. and Fatma, M. (2016b), "The concept of online corporate brand experience: an empirical assessment", Marketing Intelligence \& Planning, Vol. 34 No. 5, pp. 711-730.

Khan, I. and Fatma, M. (2017), "Antecedents and outcomes of brand experience: an empirical study", Journal of Brand Management, Vol. 24 No. 5, pp. 439-452.

Klein, J.F., Falk, T., Esch, F.R. and Gloukhovtsev, A. (2016), "Linking pop-up brand stores to brand experience and word of mouth: the case of luxury retail", Journal of Business Research, Vol. 69 No. 12, pp. 5761-5767.

Koronaki, E., Kyrousi, A.G. and Panigyrakis, G.G. (2017), "The emotional value of artsbased initiatives: strengthening the luxury brand-consumer relationship", Journal of Business Research, Vol. 85, pp. 406-413.

Kruger, L.M. (2018), "Brand loyalty: Exploring self-brand connection and brand experience", Journal of Product \& Brand Management, Vol. 27 No. 2, pp. 172-184.

Lambert-Pandraud, R. and Laurent, G. (2010), "Why do older consumers buy older brands? 
The role of attachment and declining innovativeness", Journal of Marketing, Vol. 74 No. 5, pp. 104-121.

Lanier Jr, C.D. and Rader, C.S. (2015), "Consumption experience: an expanded view", Marketing Theory, Vol. 15 No. 4, pp. 487-508.

Larsen, R.J. and Diener, E. (1987), "Affect intensity as an individual difference characteristic: a review", Journal of Research in Personality, Vol. 21 No. 1, pp. 1-39.

Lawton, M.P., Kleban, M.H., Rajagopal, D. and Dean, J. (1992), "Dimensions of affective experience in three age groups", Psychology and Aging, Vol. 7, No. 2, pp. 171-184.

Lemon, K.N. and Verhoef, P.C. (2016), "Understanding customer experience throughout the customer journey", Journal of Marketing, Vol. 80 No. 6, pp. 69-96.

Li, F., Zhou, N., Kashyap, R. and Yang, Z. (2008), "Brand trust as second-order factor: an alternative measurement model", The Market Research Society, Vol. 50 No. 6, pp. 817839.

Lin, Y.H. (2015), "Innovative brand experience's influence on brand equity and brand satisfaction", Journal of Business Research, Vol. 68 No. 11, pp. 2254-2259.

Lindell, M.K. and Whitney, D.J. (2001), "Accounting for common method variance in crosssectional research designs", Journal of Applied Psychology, Vol. 86 No. 1, 114-121.

Louis, D. and Lombart, C. (2010), "Impact of brand personality on three major relational consequences (trust, attachment, and commitment to the brand)", Journal of Product \& Brand Management, Vol. 19 No. 2, pp. 114-130.

Loureiro, S.M.C. and Roschk, H. (2014), "Differential effects of atmospheric cues on emotions and loyalty intention with respect to age under online/offline environment", Journal of Retailing and Consumer Services, Vol. 21 No. 2, pp. 211-219.

Lubin, B., Zuckerman, M., Breytspraak, L.M., Bull, N.C., Gumbhir, A.K. and Rinck, C.M. (1988), "Affects, demographic variables, and health", Journal of Clinical Psychology, Vol. 44 No. 2, pp. 131-141.

Malär, L., Krohmer, H., Hoyer, W.D. and Nyffenegger, B. (2011), "Emotional brand attachment and brand personality: the relative importance of the actual and the ideal self", Journal of Marketing, Vol. 75 No. 4, pp. 35-52.

Matzler, K., Bidmon, S. and Grabner-Kräuter, S. (2006), "Individual determinants of brand affect: the role of the personality traits of extraversion and openness to experience", Journal of Product \& Brand Management, Vol. 15 No. 7, pp. 427-434.

Matzler, K., Pichler, E.A. and Hemetsberger A. (2007), "Who is spreading the word? The positive influence of extraversion on consumer passion and brand evangelism", Proceedings of the American Marketing Association.

Mayer, R.C., Davis, J.H. and Schoorman, F.D. (1995), "An integrative model of organizational trust”, Academy of Management Review, Vol. 20 No. 3, pp. 709-734.

Merrilees, B. (2016), "Interactive brand experience pathways to customer-brand engagement and value co-creation", Journal of Product \& Brand Management, Vol. 25 No. 5, 402408.

Merrilees, B. (2017), "Experience-centric branding: challenges and advancing a new mantra for corporate brand governance", Journal of Brand Management, Vol. 24 No. 1, pp. 113.

McKay-Nesbitt, J., Manchanda, R.V., Smith, M.C. and Huhmann, B.A. (2011), "Effects of age, need for cognition, and affective intensity on advertising effectiveness", Journal of Business Research, Vol. 64 No. 1, pp. 12-17. 
McLean, G. and Wilson, A. (2016), "Evolving the online customer experience... is there a role for online customer support?", Computers in Human Behavior, Vol. 60, pp. 602610.

Meyers-Levy, J. and Loken, B. (2015), "Revisiting gender differences: what we know and what lies ahead", Journal of Consumer Psychology, Vol. 25 No. 1, pp. 129-149.

Mikulincer, M. and Shaver, P.R. (2007), Attachment in adulthood: Structure, dynamics, and change. Guilford Press.

Mishra, A.A. (2014), "Shopping value, satisfaction, and behavioral intentions: a sociodemographic and interproduct category study on private label brands", Journal of Global Marketing, Vol. 27 No. 4, pp. 226-246.

Morgan-Thomas, A. and Veloutsou, C. (2013), "Beyond technology acceptance: Brand relationships and online brand experience", Journal of Business Research, Vol. 66 No. 1, pp. 21-27.

Mulhern, F.J., Williams, J.D. and Leone, R.P. (1998), "Variability of brand price elasticities across retail stores: ethnic, income, and brand determinants", Journal of Retailing, Vol. 74 No. 3, pp. 427-446.

Ng, T.W., Eby, L.T., Sorensen, K.L. and Feldman, D.C. (2005), "Predictors of objective and subjective career success: A meta-analysis", Personnel Psychology, Vol. 58 No. 2, pp. 367-408.

Ngo, L.V., Northey, G., Duffy, S. and Thao, H.T.P. (2016), "Perceptions of others, mindfulness, and brand experience in retail service setting", Journal of Retailing and Consumer Services, Vol. 33, pp. 43-52.

Nitzl, C., Roldan, J.L. and Cepeda-Carrion, G. (2016), "Mediation analysis in partial least squares path modeling: helping researchers discuss more sophisticated models", Industrial Management \& Data Systems, Vol. 116 No. 9, pp. 1849-1864.

Nysveen, H., Pedersen, P.E. and Skard, S. (2013), "Brand experiences in service organizations: exploring the individual effects of brand experience dimensions", Journal of Brand Management, Vol. 20 No. 5, pp. 404-423.

Orgeta, V. (2009), "Specificity of age differences in emotion regulation", Aging and Mental Health, Vol. 13 No. 6, pp. 818-826.

Park, C.W., MacInnis, D.J., Priester, J., Eisingerich, A.B. and Iacobucci, D. (2010), "Brand attachment and brand attitude strength: conceptual and empirical differentiation of two critical brand equity drivers", Journal of Marketing, Vol. 74 No. 6, pp. 1-17.

Park, C.W., MacInnis, D.J. and Priester, J.R. (2006), "Beyond attitudes: attachment and consumer behavior", Seoul National Journal, Vol. 12 No. 2, pp. 3-36.

Patwardhan, H. and Balasubramanian, S.K. (2011), "Brand romance: a complementary approach to explain emotional attachment toward brands", Journal of Product \& Brand Management, Vol. 20 No. 4, pp. 297-308.

Patwardhan, H. and Balasubramanian, S.K. (2013), "Reflections on emotional attachment to brands: brand romance and brand love", Journal of Customer Behaviour, Vol. 12 No. 1, pp. 73-79.

Pine, B.J. and Gilmore, J.H. (1999), The experience economy: work is theatre \& every business a stage, Harvard Business Press.

Podsakoff, P.M., MacKenzie, S.B., Lee, J.Y. and Podsakoff, N.P. (2003), "Common method biases in behavioral research: a critical review of the literature and recommended remedies", Journal of Applied Psychology, Vol. 88 No. 5, pp. 879-903.

Ponchio, M.C. and Aranha, F. (2008), "Materialism as a predictor variable of low income 
consumer behavior when entering into installment plan agreements", Journal of Consumer Behaviour, Vol. 7 No. 1, pp. 21-34.

Proksch, M., Orth, U.R. and Cornwell, T.B. (2015), "Competence enhancement and anticipated emotion as motivational drivers of brand attachment", Psychology \& Marketing, Vol. 32 No. 9, pp. 934-949.

Rempel, J.K., Holmes, J.G. and Zanna, M.P. (1985), "Trust in close relationships", Journal of Personality and Social Psychology, Vol. 49 No. 1, pp. 95-112.

Rigdon, E.E. (2016), "Choosing PLS path modeling as analytical method in European management research: a realist perspective", European Management Journal, Vol. 34 No. 6, pp. 598-605.

Ringle, C.M, Wende, S. and Becker, J. (2015), SmartPLS 3 (Version 3.2.3). Boenningstedt, Germany: SmartPLS GmbH.

Rosa-Díaz, I.M. (2004), "Price knowledge: effects of consumers' attitudes towards prices, demographics, and socio-cultural characteristics", Journal of Product \& Brand Management, Vol. 13 No. 6, pp. 406-428.

Roswinanto, W. and Strutton, D. (2014), "Investigating the advertising antecedents to and consequences of brand experience", Journal of Promotion Management, Vol. 20 No. 5, pp. 607-627.

Rubin, Z. (1975), "Disclosing oneself to a stranger: reciprocity and its limits", Journal of Experimental Social Psychology, Vol. 11 No. 3, pp. 233-260.

Sanchez-Franco, M.J., Villarejo-Ramos, A.F. and Martin-Velicia, F.A. (2009), "The moderating effect of gender on relationship quality and loyalty toward Internet service providers", Information \& Management, Vol. 46 No. 3, pp. 196-202.

Sarstedt, M., Henseler, J. and Ringle, C.M. (2011), "Multigroup analysis in partial least squares (PLS) path modeling: alternative methods and empirical results", Advances in International Marketing, Vol. 22, pp. 195-218.

Sarstedt, M., Ringle, C.M., Smith, D., Reams, R. and Hair, J.F. (2014), "Partial least squares structural equation modeling (PLS-SEM): a useful tool for family business researchers", Journal of Family Business Strategy, Vol. 5 No. 1, pp. 105-115.

Sarstedt, M., Bengart, P., Shaltoni, A.M. and Lehmann, S. (2018), "The use of sampling methods in advertising research: a gap between theory and practice", International Journal of Advertising, Vol. 37 No. 4, pp. 650-663.

Schifferstein, H.N.J. (2006), "The relative importance of sensory modalities in product usage: a study of self-reports", Acta Psychologica, Vol. 121 No. 1, pp. 41-64.

Schmalz, S. and Orth, U.R. (2012), "Brand attachment and consumer emotional response to unethical firm behavior", Psychology \& Marketing, Vol. 29 No. 11, pp. 869-884.

Schmitt, B. (1999), Experiential Marketing, New York: Free Press.

Schmitt, B., Joško Brakus, J. and Zarantonello, L. (2015), "From experiential psychology to consumer experience", Journal of Consumer Psychology, Vol. 25 No. 1, pp. 166-171.

Schoorman, F.D., Mayer, R.C. and Davis, J.H. (2007), "An integrative model of organizational trust: Past, present, and future", Academy of Management Review, Vol. 32, No. 2, pp. 344-354.

Shamim, A. and Butt, M.M. (2013), "A critical model of brand experience consequences", Asia Pacific Journal of Marketing and Logistics, Vol. 25 No. 1, pp. 102-117.

Shaver, P.R., Mikulincer, M. and Cassidy J. (2018), "Attachment, caregiving in couple relationships, and prosocial behavior in the wider world", Current Opinion in Psychology, https://doi.org/10.1016/j.copsyc.2018.02.009 
Spurk, D. and Abele, A.E. (2011), "Who earns more and why? A multiple mediation model from personality to salary", Journal of Business and Psychology, Vol. 26 No. 1, pp. 87103.

Steinberg, L., Albert, D., Cauffman, E., Banich, M., Graham, S. and Woolard, J. (2008), “Age differences in sensation seeking and impulsivity as indexed by behavior and self-report: evidence for a dual systems model”, Developmental Psychology, Vol. 44 No. 6, pp. 1764-1778.

Sudbury-Riley, L. and Edgar, L. (2016), "Why older adults show preference for rational over emotional advertising appeals", Journal of Advertising Research, Vol. 56 No. 4, pp. 441-455.

Tafesse, W. (2016), "An experiential model of consumer engagement in social media”, Journal of Product \& Brand Management, Vol. 25 No. 5, 424-434.

Thau, S., Crossley, C., Bennett, R.J. and Sczesny, S. (2007), "The relationship between trust, attachment, and antisocial work behaviors", Human Relations, Vol. 60 No. 8, pp. 11551179.

Thomson, M., MacInnis, D.J. and Park, C.W. (2005), "The ties that bind: measuring the strength of consumers' emotional attachments to brands", Journal of Consumer Psychology, Vol. 15 No. 1, pp. 77-91.

Trudeau H.S. and Shobeiri, S. (2016), "Does social currency matter in creation of enhanced brand experience?”, Journal of Product \& Brand Management, Vol. 25 No. 1, pp. 98114.

Vlachos, P.A., Theotokis, A., Pramatari, K. and Vrechopoulos, A. (2010), "Consumer-retailer emotional attachment: some antecedents and the moderating role of attachment anxiety”, European Journal of Marketing, Vol. 44 No. 9/10, pp. 1478-1499.

Wakefield, K.L. and Inman, J.J. (2003), "Situational price sensitivity: the role of consumption occasion, social context and income”, Journal of Retailing, Vol. 79 No. 4, pp. 199-212.

Walter, U., Edvardsson, B. and Öström, Å. (2010), "Drivers of customers' service experiences: A study in the restaurant industry", Managing Service Quality, Vol. 20 No. 3, pp. 236-258.

Williams, P. and Drolet, A. (2005), "Age-related differences in responses to emotional advertisements", Journal of Consumer Research, Vol. 32 No. 3, pp. 343-354.

Xie, L., Poon, P. and Zhang, W. (2017), "Brand experience and customer citizenship behavior: the role of brand relationship quality", Journal of Consumer Marketing, Vol. 34 No. 3, pp. 268-280.

Zarantonello, L. and Schmitt, B.H. (2010), "Using the brand experience scale to profile consumers and predict consumer behavior", Journal of Brand Management, Vol. 17 No. 7, pp. 532-540.

Zarantonello, L. and Schmitt, B.H. (2013), "The impact of event marketing on brand equity: the mediating roles of brand experience and brand attitude", International Journal of Advertising, Vol. 32 No. 2, pp. 255-280.

Zarantonello, L., Romani, S., Grappi, S. and Bagozzi, R.P. (2016), "Brand hate", Journal of Product \& Brand Management, Vol. 25 No. 1, pp. 11-25.

Zhou, Z., Zhang, Q., Su, C. and Zhou, N. (2012), "How do brand communities generate brand relationships? Intermediate mechanisms", Journal of Business Research, Vol. 65 No. 7, pp. 890-895.

Zuckerman, M. (1979), Sensation seeking. John Wiley \& Sons, Inc. 
Figure 1: Conceptual Model

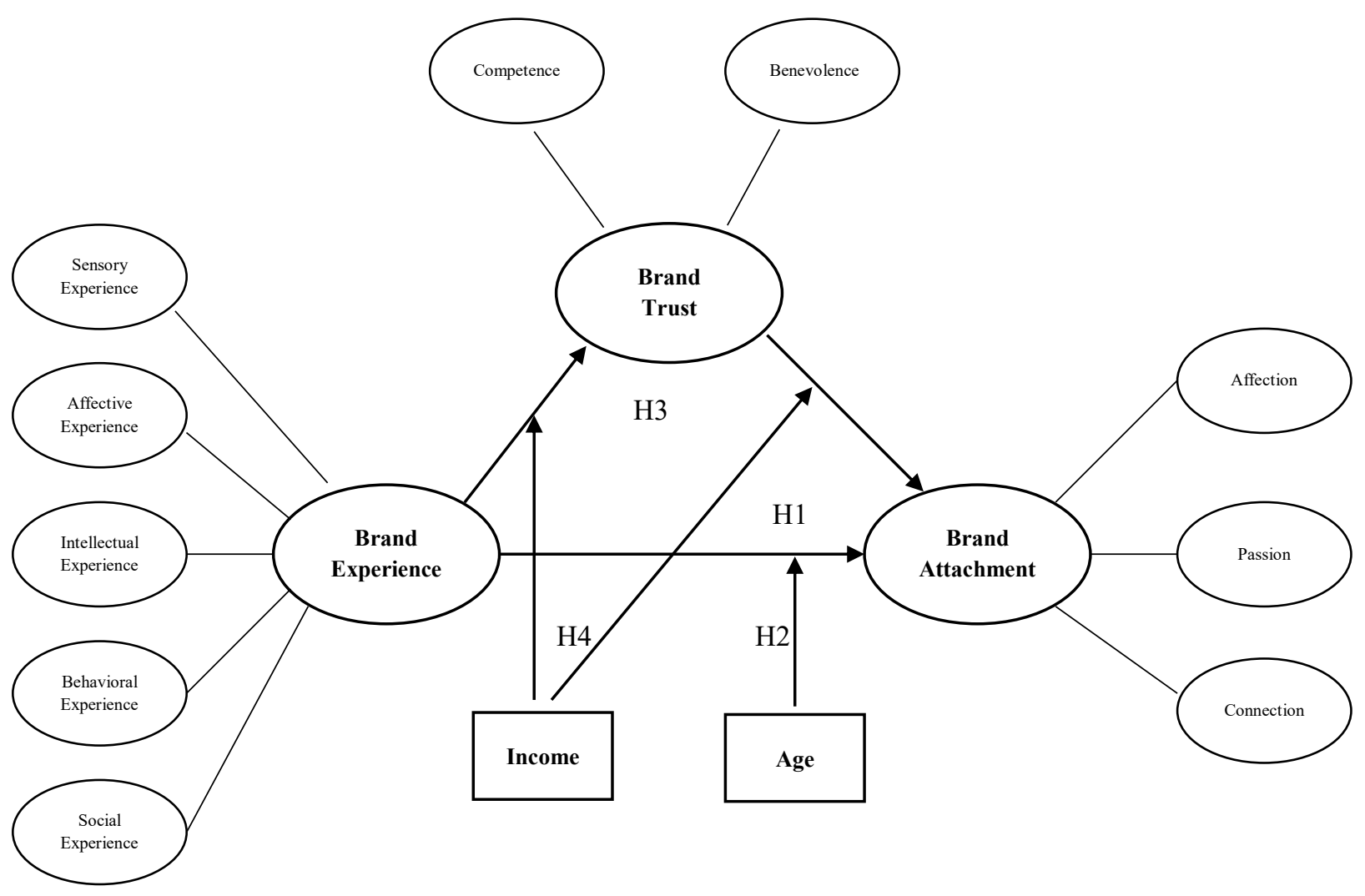


Figure 2: Synthesis of results

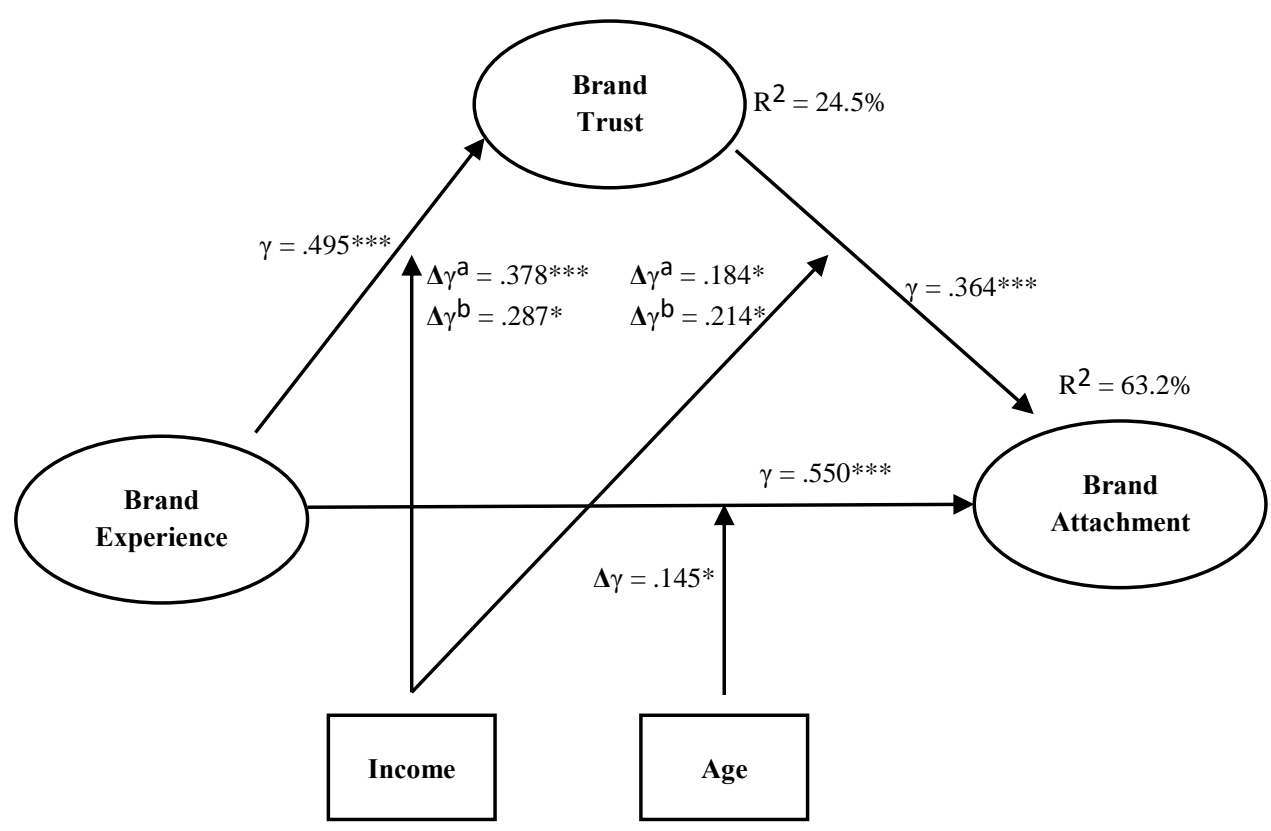

$* \mathrm{p}<.05 ; * * \mathrm{p}<.01 ; * * \mathrm{p}<.001{ }^{\mathrm{a}}$ low income versus high income; ${ }^{\mathrm{b}}$ medium income versus high income 
Table 1: Demographic Characteristics of the Sample $(N=334)$

\begin{tabular}{lrr}
\hline Categories & $N$ & $\%$ \\
\hline Age & & \\
$18-25$ & 161 & 48.2 \\
$26-34$ & 144 & 43.1 \\
$35-45$ & 29 & 8.7 \\
Gender & & \\
Male & 207 & 62.0 \\
Female & 127 & 38.0 \\
Monthly Household Income & & \\
Low (<S/2000) & 128 & 38.4 \\
Medium (S/2000-S/4000) & 100 & 29.9 \\
High (>S/4000) & 106 & 31.7 \\
Occupational category & & \\
Undergraduate & 128 & 38.4 \\
Engineer & 109 & 32.5 \\
Employee & 44 & 13.2 \\
Manager & 20 & 6.0 \\
Others & 33 & 9.9 \\
\hline
\end{tabular}




\section{Table 2: Measurement Items and Variable Sources}

\begin{tabular}{|c|c|c|}
\hline Construct & Measurement items & Sources \\
\hline Brand & Sensorial & Adapted from \\
\hline Experience & $\begin{array}{l}\text { This brand makes a positive impression on my visual sense or other senses. } \\
\text { (ESen1) } \\
\text { I find this brand interesting in a sensory way. (ESen2) } \\
\text { Affective } \\
\text { This brand induces agreeable feelings and sentiments. (EAff1) } \\
\text { I have positive emotions for this brand. (EAff2) } \\
\text { Intellectual } \\
\text { I engage in thinking when I encounter this brand. (EInt1) } \\
\text { This brand stimulates my curiosity and problem solving. (EInt2.) } \\
\text { Behavioral } \\
\text { I engage in physical actions and behaviors when I use this brand. (EBeh1) } \\
\text { This brand is action oriented. (EBeh2) } \\
\text { Social } \\
\text { This brand makes me feel accepted. (ESoc1) } \\
\text { This brand makes me feel special in comparison to users of other brands. } \\
\text { (ESoc2) } \\
\text { This brand stimulates me to share emotions and passions with other brand } \\
\text { users. (ESoc3) } \\
\text { This brand makes me feel a strong connection towards other brand users. } \\
\text { (ESoc4) }\end{array}$ & $\begin{array}{r}\text { Brakus et al. } \\
(2009)\end{array}$ \\
\hline Brand & Competence & Adapted from \\
\hline Trust & $\begin{array}{l}\text { This brand does a good job. (TCom1) } \\
\text { I expect the brand to deliver on its promise. (TCom2) } \\
\text { I am confident in the brand's ability to perform well. (TCom3) } \\
\text { The quality of this brand has been very consistent. (TCom4) } \\
\text { Benevolence } \\
\text { The brand has good intentions towards its consumers. (TBen1) } \\
\text { It will respond constructively if I have any product-related problems. (TBen2) } \\
\text { It would be do its best to help me if I had a problem. (TBen3) } \\
\text { It cares about my needs. (TBen4) } \\
\text { This brand gives me a sense of security. (TBen5) }\end{array}$ & Li et al. (2008) \\
\hline Brand & Affection & Adapted from \\
\hline Attachment & $\begin{array}{l}\text { Affectionate. (AAff1) } \\
\text { Friendly. (AAff2) } \\
\text { Loved (AAff3) } \\
\text { Passion } \\
\text { Passionate. (APas1) } \\
\text { Delighted. (APas2) } \\
\text { Captivated. (APas3) } \\
\text { Connection } \\
\text { Connected (ACon1) } \\
\text { Bonded (ACon2) } \\
\text { Attached (ACon3) }\end{array}$ & $\begin{array}{l}\text { Thomson et al. } \\
\text { (2005) }\end{array}$ \\
\hline
\end{tabular}


Table 3: Measurement Properties ( $N$ = 334)

\begin{tabular}{|c|c|c|c|c|}
\hline Constructs & Items & Means (SD) & $\begin{array}{l}\text { Standardized } \\
\text { loading }\end{array}$ & $\begin{array}{l}\text { Reliability } \\
\text { and validity }\end{array}$ \\
\hline \multirow{17}{*}{$\begin{array}{l}\text { Brand } \\
\text { Experience }\end{array}$} & Sensorial & & & $\mathrm{CR}=.935$ \\
\hline & ESen1 & $4.76(1.51)$ & .940 & $\mathrm{AVE}=.878$ \\
\hline & ESen2 & $4.78(1.53)$ & .934 & \\
\hline & Affective & & & $\mathrm{CR}=.943$ \\
\hline & EAff1 & $4.25(1.58)$ & 942 & $\mathrm{AVE}=.892$ \\
\hline & EAff2 & $4.41(1.59)$ & .947 & \\
\hline & Intellectual & & & $\mathrm{CR}=.894$ \\
\hline & EInt1 & $3.63(1.65)$ & .880 & $\mathrm{AVE}=.808$ \\
\hline & EInt2 & 3.78 (1.72) & .917 & \\
\hline & Behavioral & & & $\mathrm{CR}=.869$ \\
\hline & EBeh1 & $4.06(1.58)$ & .884 & $\mathrm{AVE}=.769$ \\
\hline & EBeh2 & $4.76(1.58)$ & .870 & \\
\hline & Social & & & $\mathrm{CR}=.877$ \\
\hline & ESoc1 & 4.18 (1.69) & .813 & $\mathrm{AVE}=.641$ \\
\hline & ESoc2 & $3.80(1.71)$ & .706 & \\
\hline & ESoc3 & $4.41(1.63)$ & .857 & \\
\hline & ESoc4 & $4.41(1.46)$ & .819 & \\
\hline \multirow{11}{*}{$\begin{array}{l}\text { Brand Trust } \\
\left(\mathrm{R}^{2}=24.5 \%\right)\end{array}$} & Competence & & & $\mathrm{CR}=.947$ \\
\hline & TCom1 & $5.79(1.09)$ & .917 & $\mathrm{AVE}=.817$ \\
\hline & TCom2 & $5.56(1.14)$ & .898 & \\
\hline & TCom3 & $5.64(1.13)$ & .907 & \\
\hline & TCom4 & $5.68(1.10)$ & .894 & \\
\hline & Benevolence & & & $\mathrm{CR}=.930$ \\
\hline & TBen1 & $5.69(1.17)$ & .839 & $\mathrm{AVE}=.727$ \\
\hline & TBen2 & $5.41(1.18)$ & .863 & \\
\hline & TBen3 & $5.23(1.26)$ & .885 & \\
\hline & TBen4 & $5.15(1.27)$ & .845 & \\
\hline & TBen5 & $5.48(1.29)$ & .830 & \\
\hline \multirow{12}{*}{$\begin{array}{l}\text { Brand } \\
\text { Attachment } \\
\left(\mathrm{R}^{2}=63.2 \%\right)\end{array}$} & Affection & & & $\mathrm{CR}=.908$ \\
\hline & AAff1 & $4.63(1.45)$ & .886 & $\mathrm{AVE}=.768$ \\
\hline & AAff2 & $5.16(1.31)$ & .906 & \\
\hline & AAff3 & $5.25(1.39)$ & .836 & \\
\hline & Passion & & & $\mathrm{CR}=.933$ \\
\hline & APas1 & $3.99(1.58)$ & 906 & $\mathrm{AVE}=.823$ \\
\hline & APas2 & $4.61(1.51)$ & 901 & \\
\hline & APas3 & $4.29(1.51)$ & .914 & \\
\hline & Connection & & & $\mathrm{CR}=.941$ \\
\hline & ACon1 & $4.70(1.42)$ & .912 & $\mathrm{AVE}=.843$ \\
\hline & ACon2 & $4.36(1.51)$ & .939 & \\
\hline & ACon3 & $4.42(1.58)$ & .903 & \\
\hline
\end{tabular}


Table 4: Discriminant Validity Results

\begin{tabular}{lccccccccc}
\hline \multicolumn{1}{c}{ Constructs } & 1 & 2 & 3 & 4 & 5 & 6 & 7 & 8 & 9 \\
\hline 1. Sensorial & & & & & & & & & \\
2. Affective & .688 & & & & & & & & \\
3. Intellectual & .589 & .662 & & & & & & & \\
4. Behavioral & .680 & .881 & .728 & & & & & & \\
5. Social & .591 & .651 & .826 & .809 & & & & & \\
6. Competence & .369 & .569 & .262 & .569 & .429 & & & & \\
7. Benevolence & .367 & .624 & .354 & .624 & .517 & .881 & & & \\
8. Affection & .560 & .660 & .466 & .778 & .613 & .759 & .779 & & \\
9. Passion & .577 & .763 & .579 & .802 & .661 & .505 & .551 & .855 & \\
10. Connection & .549 & .677 & .543 & .729 & .623 & .519 & .592 & .849 & .836 \\
\hline
\end{tabular}


Table 5: Results of Hypothesis Testing

\begin{tabular}{clllc}
\hline Hypothesis & Relationships & $\begin{array}{l}\text { Path coefficient } \\
(\gamma)\end{array}$ & $\begin{array}{l}\text { CIs (Bias } \\
\text { corrected) }\end{array}$ & Supported \\
\hline H1 & Brand Experience -> Brand & $.550^{* * *}$ & {$[.458, .631]$} & Yes \\
& Attachment & & & \\
& Brand Experience -> Brand Trust & $.495 * * *$ & {$[.396, .582]$} & \\
& Brand Trust -> Brand Attachment & $.364 * *$ & {$[.268, .458]$} & \multirow{2}{*}{ Yes } \\
& Brand Experience -> Brand Trust & $.180^{* * *}$ & {$[.128, .240]$} & \\
\hline
\end{tabular}

All coefficients are significant at $\mathrm{p}<.01$ 
Table 6: Results of Measurement Invariance Testing for the Two Age Groups

\begin{tabular}{|c|c|c|c|c|c|c|c|}
\hline \multirow[t]{2}{*}{ Constructs } & \multirow{2}{*}{$\begin{array}{l}\text { Configural } \\
\text { invariance } \\
\text { (Same } \\
\text { algorithms } \\
\text { for both } \\
\text { groups) }\end{array}$} & \multicolumn{2}{|c|}{$\begin{array}{c}\text { Compositional } \\
\text { invariance } \\
(\text { Correlation }=1)\end{array}$} & \multicolumn{2}{|c|}{ Equal mean value } & \multicolumn{2}{|c|}{ Equal variance } \\
\hline & & $\begin{array}{l}C= \\
1\end{array}$ & $\begin{array}{l}\text { Confidence } \\
\text { Interval (CIs) }\end{array}$ & Differ. & $\begin{array}{c}\text { Confidence } \\
\text { Interval (CIs) }\end{array}$ & Differ. & $\begin{array}{l}\text { Confidence } \\
\text { Interval } \\
\text { (CIs) }\end{array}$ \\
\hline $\begin{array}{l}\text { Brand } \\
\text { Experience }\end{array}$ & Yes & 1.000 & {$[.999,1.000]$} & -.037 & {$[-.220, .206]$} & .048 & {$[-.321, .302]$} \\
\hline Sensorial & Yes & 1.000 & {$[1.000,1.000]$} & -.142 & {$[-.217, .209]$} & .025 & {$[-.332, .324]$} \\
\hline Affective & Yes & 1.000 & {$[.999,1.000]$} & .008 & {$[-.217, .209]$} & .125 & {$[-.282, .266]$} \\
\hline Intellectual & Yes & 1.000 & {$[.998,1.000]$} & .049 & {$[-.210, .213]$} & -.123 & {$[-.246, .247]$} \\
\hline Behavioral & Yes & 1.000 & {$[.999,1.000]$} & -.047 & {$[-.220, .211]$} & .030 & {$[-.308, .307]$} \\
\hline Social & Yes & .999 & {$[.998,1.000]$} & -.025 & {$[-.214, .213]$} & .088 & {$[-.316, .304]$} \\
\hline $\begin{array}{l}\text { Brand } \\
\text { Trust }\end{array}$ & Yes & 1.000 & {$[1.000,1.000]$} & -.032 & {$[-.213, .204]$} & -.164 & {$[-.474, .470]$} \\
\hline Competence & Yes & 1.000 & {$[1.000,1.000]$} & -.023 & {$[-.211, .203]$} & -.191 & {$[-.513, .501]$} \\
\hline Benevolence & Yes & 1.000 & {$[1.000,1.000]$} & -.037 & {$[-.211, .210]$} & -.141 & {$[-.397, .397]$} \\
\hline $\begin{array}{l}\text { Brand } \\
\text { Attachment }\end{array}$ & Yes & 1.000 & {$[1.000,1.000]$} & .016 & {$[-.217, .211]$} & -.005 & {$[-.362, .361]$} \\
\hline Affection & Yes & 1.000 & {$[1.000,1.000]$} & -.009 & {$[-.217, .211]$} & .008 & {$[-.392, .382]$} \\
\hline Passion & Yes & 1.000 & {$[1.000,1.000]$} & .125 & {$[-.222, .211]$} & .044 & {$[-.311, .310]$} \\
\hline Connection & Yes & 1.000 & {$[1.000,1.000]$} & -.074 & {$[-.220, .211]$} & .079 & {$[-.329, .309]$} \\
\hline
\end{tabular}


Table 7: Results of Hypothesis Testing - Moderation by Age

\begin{tabular}{|c|c|c|c|c|c|c|c|c|}
\hline Hypothesis & Relationships & $\begin{array}{l}\text { Path } \\
\text { coeff. } \\
\text { Younger }\end{array}$ & $\begin{array}{l}\text { Path } \\
\text { coeff. } \\
\text { Older }\end{array}$ & $\begin{array}{l}\text { CIs (Bias } \\
\text { corrected) } \\
\text { Younger }\end{array}$ & $\begin{array}{l}\text { CIs (Bias } \\
\text { corrected) } \\
\text { Older }\end{array}$ & $\begin{array}{l}\text { Path } \\
\text { coeff. } \\
\text { Diff. }\end{array}$ & $\begin{array}{l}\text { p-value } \\
\text { Henseler's } \\
\text { bootstrap }\end{array}$ & Supported \\
\hline \multirow[t]{4}{*}{ H2 } & $\begin{array}{l}\text { Brand Experience -> } \\
\text { Brand Attachment }\end{array}$ & $.624 * * *$ & $.480 * * *$ & {$[.519, .721]$} & {$[.347, .605]$} & .145 & $.025^{*}$ & \multirow[t]{4}{*}{ Yes } \\
\hline & $\begin{array}{l}\text { Brand Experience -> } \\
\text { Brand Trust }\end{array}$ & $.516^{* * * *}$ & $.476^{* * *}$ & {$[.378, .624]$} & {$[.315, .595]$} & .040 & .335 & \\
\hline & $\begin{array}{l}\text { Brand Trust -> } \\
\text { Brand Attachment }\end{array}$ & $.312 * * *$ & $.412 * * *$ & {$[.195, .425]$} & {$[.275, .547]$} & .101 & .862 & \\
\hline & $\begin{array}{l}\text { Brand Experience -> } \\
\text { Brand Trust -> } \\
\text { Brand Attachment }\end{array}$ & $.161 * * *$ & $.196^{* * * *}$ & {$[.092, .243]$} & {$[.127, .284]$} & .035 & .739 & \\
\hline
\end{tabular}


Table 8: Results of Hypothesis Testing - Moderation by Income

\begin{tabular}{|c|c|c|c|c|c|c|c|c|}
\hline Hypothesis & Relationships & $\begin{array}{l}\text { Path } \\
\text { coeff. } \\
\text { Low }\end{array}$ & $\begin{array}{l}\text { Path } \\
\text { coeff. } \\
\text { Medium }\end{array}$ & $\begin{array}{l}\text { CIs (Bias } \\
\text { corrected) } \\
\text { Low }\end{array}$ & $\begin{array}{l}\text { CIs (Bias } \\
\text { corrected) } \\
\text { Medium }\end{array}$ & $\begin{array}{l}\text { Path } \\
\text { coeff. } \\
\text { Diff. }\end{array}$ & $\begin{array}{l}\text { p-value } \\
\text { Henseler's } \\
\text { MGA }\end{array}$ & Supported \\
\hline \multirow{4}{*}{$\begin{array}{c}1 \text { (Low } \\
\text { income) vs. } \\
2 \text { (Medium } \\
\text { income) }\end{array}$} & $\mathrm{BE} \rightarrow \mathrm{BA}$ & $.526 * * *$ & $.506 * * *$ & {$[.394, .656]$} & {$[.358, .654]$} & .020 & .422 & \\
\hline & $\mathrm{BE}->\mathrm{BT}$ & $.596 * * *$ & $.205^{*}$ & {$[.461, .691]$} & {$[.323, .636]$} & .091 & .175 & \\
\hline & $\mathrm{BT} \rightarrow \mathrm{BA}$ & $.403 * * *$ & $.433 * *$ & {$[.271, .532]$} & {$[.270, .590]$} & .030 & .613 & \\
\hline & $\mathrm{BE}->\mathrm{BT}->\mathrm{BA}$ & $.240^{* * *}$ & $.219^{* *}$ & {$[.153, .337]$} & {$[.123, .329]$} & .021 & .379 & No \\
\hline \multirow{5}{*}{$\begin{array}{c}1(\text { Low } \\
\text { income) vs. } \\
3 \text { (High } \\
\text { income) }\end{array}$} & & Low & High & Low & High & & & \\
\hline & $\mathrm{BE}->\mathrm{BA}$ & $.526 * * *$ & $.603 * * *$ & {$[.382, .652]$} & {$[.417, .734]$} & .077 & .766 & \\
\hline & $\mathrm{BE}->\mathrm{BT}$ & $.596 * * *$ & $.219^{*}$ & {$[.474, .695]$} & {$[-.015, .442]$} & .378 & $.001 * * *$ & \\
\hline & $\mathrm{BT}->\mathrm{BA}$ & $.403^{* * *}$ & $.219^{* *}$ & {$[.265, .530]$} & {$[.048, .413]$} & .184 & $.050^{*}$ & \\
\hline & BE $->$ BT $>$ BA & $.240 * * *$ & .048 & {$[.155, .339]$} & {$[.004, .133]$} & .192 & $.001 * * *$ & Yes \\
\hline \multirow{5}{*}{$\begin{array}{c}2 \text { (Medium } \\
\text { income) vs. } \\
3 \text { (High } \\
\text { income) }\end{array}$} & & Medium & High & Medium & High & & & \\
\hline & $\mathrm{BE} \rightarrow \mathrm{BA}$ & $.506 * * *$ & $.603^{* * *}$ & {$[.356, .652]$} & {$[.404, .727]$} & .097 & .809 & \\
\hline & $\mathrm{BE}->\mathrm{BT}$ & $.505^{* * *}$ & $.219^{*}$ & {$[.341, .642]$} & {$[-.019, .429]$} & .287 & $.021^{*}$ & \\
\hline & $\mathrm{BT}->\mathrm{BA}$ & $.433^{* * *}$ & $.219 * *$ & {$[.272, .577]$} & {$[.044, .419]$} & .214 & $.045^{*}$ & \\
\hline & $\mathrm{BE} \rightarrow \mathrm{BT} \rightarrow \mathbf{B A}$ & $.219 * * *$ & .048 & {$[.128, .341]$} & {$[.005, .130]$} & .171 & $.002 * * *$ & Yes \\
\hline
\end{tabular}


Table 9: Means Scores between Hedonic Brands and Utilitarian Brands

\begin{tabular}{lccll}
\hline $\begin{array}{l}\text { Experience } \\
\text { dimensions }\end{array}$ & $\begin{array}{c}\text { Cluster I } \\
(5 \text { hedonic } \\
\text { brands })\end{array}$ & $\begin{array}{c}\text { Cluster II } \\
(5 \text { utilitarian } \\
\text { brands })\end{array}$ & F-ratio & Sig. \\
\hline Sensorial & 5.07 & 4.31 & 19.575 & .002 \\
Affective & 4.60 & 3.74 & 14.214 & .005 \\
Intellectual & 3.95 & 3.65 & 1.165 & .312 \\
Behavioral & 4.65 & 3.96 & 5.166 & .050 \\
Social & 4.38 & 3.85 & 7.127 & .028 \\
\hline
\end{tabular}


Table 10: Robustness of the model - Type of Brands

\begin{tabular}{llllllc}
\hline Relationships & $\begin{array}{l}\text { Path coeff. } \\
\text { Utilitarian }\end{array}$ & $\begin{array}{l}\text { Path } \\
\text { coeff. } \\
\text { Hedonic }\end{array}$ & $\begin{array}{l}\text { CIs (Bias } \\
\text { corrected) } \\
\text { Utilitarian }\end{array}$ & $\begin{array}{l}\text { CIs (Bias } \\
\text { corrected) } \\
\text { Hedonic }\end{array}$ & $\begin{array}{l}\text { Path } \\
\text { coeff. } \\
\text { Diff. }\end{array}$ & $\begin{array}{l}\text { p-value } \\
\text { Henseler's } \\
\text { bootstrap }\end{array}$ \\
\hline $\begin{array}{l}\text { Brand experience -> } \\
\text { Brand attachment }\end{array}$ & $.440^{* * *}$ & $.615^{* * *}$ & {$[.304, .597]$} & {$[.490, .722]$} & .166 & $.040^{*}$ \\
$\begin{array}{l}\text { Brand experience -> } \\
\text { Brand trust }\end{array}$ & $.635^{* * *}$ & $.365^{* * *}$ & {$[.502, .732]$} & {$[.210, .487]$} & .270 & $.004 * * *$ \\
$\begin{array}{l}\text { Brand trust -> Brand } \\
\text { attachment }\end{array}$ & $.445^{* * *}$ & $.297^{* * *}$ & {$[.297, .569]$} & {$[.160, .441]$} & .141 & .146 \\
$\begin{array}{l}\text { Brand experience -> } \\
\text { Brand trust }>\text { Brand } \\
\text { attachment }\end{array}$ & $.108^{* * *}$ & $.282^{* * *}$ & {$[.063, .173]$} & {$[.166, .382]$} & .174 & $.997 * *$ \\
$* \mathrm{p}<.05 ; * * \mathrm{p}<.01 ; * * * \mathrm{p}<.001$ & & & & & \\
\hline
\end{tabular}




\section{Appendix 1}

Results of Invariance Measurement Testing using Permutation-Income (1vs2)

\begin{tabular}{|c|c|c|c|c|c|c|c|}
\hline \multirow[t]{2}{*}{ Constructs } & \multirow{2}{*}{$\begin{array}{l}\text { Configural } \\
\text { invariance } \\
\text { (Same } \\
\text { algorithms } \\
\text { for both } \\
\text { groups) }\end{array}$} & \multicolumn{2}{|c|}{$\begin{array}{c}\text { Compositional } \\
\text { invariance } \\
(\text { Correlation }=1)\end{array}$} & \multicolumn{2}{|c|}{ Equal mean value } & \multicolumn{2}{|c|}{ Equal variance } \\
\hline & & $\mathrm{C}=1$ & $\begin{array}{l}\text { Confidence } \\
\text { Interval (CIs) }\end{array}$ & Differ. & $\begin{array}{c}\text { Confidence } \\
\text { Interval (CIs) }\end{array}$ & Differ. & $\begin{array}{c}\text { Confidence } \\
\text { Interval } \\
(\mathrm{CIs})\end{array}$ \\
\hline $\begin{array}{l}\text { Brand } \\
\text { Experience }\end{array}$ & Yes & 1.000 & {$[.999,1.000]$} & -.185 & {$[-.262, .263]$} & .091 & {$[-.364, .374]$} \\
\hline Sensorial & Yes & 1.000 & {$[.999,1.000]$} & -.111 & {$[-.253, .264]$} & .197 & {$[-.376, .365]$} \\
\hline Affective & Yes & 1.000 & {$[.999,1.000]$} & -.188 & {$[-.262, .259]$} & .232 & {$[-.334, .342]$} \\
\hline Intellectual & Yes & .999 & {$[.997,1.000]$} & .001 & {$[-.263, .256]$} & -.167 & {$[-.301, .311]$} \\
\hline Behavioral & Yes & 1.000 & {$[.998,1.000]$} & -.237 & {$[-.265, .256]$} & .151 & {$[-.363, .366]$} \\
\hline Social & Yes & .999 & {$[.998,1.000]$} & -.184 & {$[-.264, .260]$} & -.027 & {$[-.335, .353]$} \\
\hline $\begin{array}{l}\text { Brand } \\
\text { Trust }\end{array}$ & Yes & 1.000 & {$[1.000,1.000]$} & -.240 & {$[-.259, .262]$} & -.236 & {$[-.531, .558]$} \\
\hline Competence & Yes & 1.000 & {$[1.000,1.000]$} & -.166 & {$[-.257, .260]$} & -.259 & {$[-.579, .600]$} \\
\hline Benevolence & Yes & 1.000 & {$[1.000,1.000]$} & -.286 & {$[-.259, .266]$} & -.141 & {$[-.443, .459]$} \\
\hline $\begin{array}{l}\text { Brand } \\
\text { Attachment }\end{array}$ & Yes & 1.000 & {$[1.000,1.000]$} & -.160 & {$[-.253, .260]$} & .098 & {$[-.442, .446]$} \\
\hline Affection & Yes & 1.000 & {$[.999,1.000]$} & -.210 & {$[-.259, .257]$} & .008 & {$[-.466, .479]$} \\
\hline Passion & Yes & 1.000 & {$[1.000,1.000]$} & -.154 & {$[-.253, .271]$} & .181 & {$[-.373, .387]$} \\
\hline Connection & Yes & 1.000 & {$[1.000,1.000]$} & -.083 & {$[-.254, .258]$} & .044 & {$[-.383, .398]$} \\
\hline
\end{tabular}

\section{Appendix 2}

\section{Results of Invariance Measurement Testing using Permutation-Income (1vs3)}

\begin{tabular}{|c|c|c|c|c|c|c|c|}
\hline \multirow[t]{2}{*}{ Constructs } & \multirow{2}{*}{$\begin{array}{l}\text { Configural } \\
\text { invariance } \\
\text { (Same } \\
\text { algorithms } \\
\text { for both } \\
\text { groups) }\end{array}$} & \multicolumn{2}{|c|}{$\begin{array}{c}\text { Compositional } \\
\text { invariance } \\
(\text { Correlation }=1)\end{array}$} & \multicolumn{2}{|c|}{ Equal mean value } & \multicolumn{2}{|c|}{ Equal variance } \\
\hline & & $\mathrm{C}=1$ & $\begin{array}{l}\text { Confidence } \\
\text { Interval (CIs) }\end{array}$ & Differ. & $\begin{array}{c}\text { Confidence } \\
\text { Interval (CIs) }\end{array}$ & Differ. & $\begin{array}{l}\text { Confidence } \\
\text { Interval } \\
\text { (CIs) }\end{array}$ \\
\hline $\begin{array}{l}\text { Brand } \\
\text { Experience }\end{array}$ & Yes & .998 & {$[.999,1.000]$} & -.347 & {$[-.255, .261]$} & .236 & {$[-.368, .358]$} \\
\hline Sensorial & Yes & 1.000 & {$[.999,1.000]$} & -.260 & {$[-.249, .262]$} & .328 & {$[-.387, .407]$} \\
\hline Affective & Yes & 1.000 & {$[1.000,1.000]$} & -.289 & {$[-.259, .250]$} & .135 & {$[-.317, .318]$} \\
\hline Intellectual & Yes & .997 & {$[.997,1.000]$} & -.070 & {$[-.262, .250]$} & -.174 & {$[-.280, .295]$} \\
\hline Behavioral & Yes & 1.000 & {$[.998,1.000]$} & -.437 & {$[-.254, .254]$} & .167 & {$[-.348, .371]$} \\
\hline Social & Yes & .999 & {$[.996,1.000]$} & -.025 & {$[-.252, .272]$} & .217 & {$[-.356, .367]$} \\
\hline Brand & Yes & 1.000 & {$[.999,1.000]$} & -.746 & {$[-.254, .260]$} & .873 & {$[-.481 .494]$} \\
\hline
\end{tabular}




\begin{tabular}{lcrrrrrr}
$\begin{array}{l}\text { Trust } \\
\text { Competence }\end{array}$ & Yes & 1.000 & {$[1.000,1.000]$} & -.650 & {$[-.251, .252]$} & .854 & {$[-.528, .532]$} \\
Benevolence & Yes & 1.000 & {$[.999,1.000]$} & -.749 & {$[-.211, .210]$} & .697 & {$[-.414, .425]$} \\
$\begin{array}{l}\text { Brand } \\
\text { Attachment }\end{array}$ & Yes & 1.000 & {$[1.000,1.000]$} & -.355 & {$[-.252, .255]$} & .361 & {$[-.396, .419]$} \\
$\begin{array}{l}\text { Affection } \\
\text { Passion }\end{array}$ & Yes & 1.000 & {$[.999,1.000]$} & -.486 & {$[-.259, .247]$} & .527 & {$[-.467, .484]$} \\
Connection & Yes & 1.000 & {$[1.000,1.000]$} & -.214 & {$[-.253, .258]$} & .310 & {$[-.356, .368]$} \\
\hline
\end{tabular}

\section{Appendix 3}

Results of Invariance Measurement Testing using Permutation-Income (2vs3)

\begin{tabular}{|c|c|c|c|c|c|c|c|}
\hline \multirow[t]{2}{*}{ Constructs } & \multirow{2}{*}{$\begin{array}{l}\text { Configural } \\
\text { invariance } \\
\text { (Same } \\
\text { algorithms } \\
\text { for both } \\
\text { groups) }\end{array}$} & \multicolumn{2}{|c|}{$\begin{array}{c}\text { Compositional } \\
\text { invariance } \\
(\text { Correlation }=1)\end{array}$} & \multicolumn{2}{|c|}{ Equal mean value } & \multicolumn{2}{|c|}{ Equal variance } \\
\hline & & $C=1$ & $\begin{array}{l}\text { Confidence } \\
\text { Interval (CIs) }\end{array}$ & Differ. & $\begin{array}{l}\text { Confidence } \\
\text { Interval (CIs) }\end{array}$ & Differ. & $\begin{array}{l}\text { Confidence } \\
\text { Interval } \\
\text { (CIs) }\end{array}$ \\
\hline $\begin{array}{l}\text { Brand } \\
\text { Experience }\end{array}$ & Yes & .999 & {$[.998,1.000]$} & -.168 & {$[-.274, .275]$} & .142 & {$[-.435, .429]$} \\
\hline Sensorial & Yes & 1.000 & {$[1.000,1.000]$} & -.160 & {$[-.282, .274]$} & .132 & {$[-.464, .473]$} \\
\hline Affective & Yes & 1.000 & {$[.999,1.000]$} & -.112 & {$[-.276, .274]$} & -.096 & {$[-.379, .363]$} \\
\hline Intellectual & Yes & .999 & {$[.998,1.000]$} & -.073 & {$[-.284, .269]$} & .006 & {$[-.312, .309]$} \\
\hline Behavioral & Yes & 1.000 & {$[.997,1.000]$} & -.218 & {$[-.268, .274]$} & .021 & {$[-.431, .444]$} \\
\hline Social & Yes & .997 & {$[.996,1.000]$} & -.124 & {$[-.268, .271]$} & .251 & {$[-.432, .427]$} \\
\hline $\begin{array}{l}\text { Brand } \\
\text { Trust }\end{array}$ & Yes & 1.000 & {$[1.000,1.000]$} & -.465 & {$[-.275, .276]$} & 1.106 & {$[-.788, .800]$} \\
\hline Competence & Yes & 1.000 & {$[1.000,1.000]$} & -.438 & {$[-.278, .276]$} & 1.112 & {$[-.825, .836]$} \\
\hline Benevolence & Yes & 1.000 & {$[1.000,1.000]$} & -.443 & {$[-.278, .273]$} & .843 & {$[-.633, .637]$} \\
\hline $\begin{array}{l}\text { Brand } \\
\text { Attachment }\end{array}$ & Yes & 1.000 & {$[1.000,1.000]$} & -.198 & {$[-.277, .273]$} & .274 & {$[-.477, .487]$} \\
\hline Affection & Yes & 1.000 & {$[.999,1.000]$} & -.269 & {$[-.276, .276]$} & .517 & {$[-.507, .518]$} \\
\hline Passion & Yes & 1.000 & {$[1.000,1.000]$} & -.062 & {$[-.275, .282]$} & 127 & {$[-.412, .427]$} \\
\hline Connection & Yes & 1.000 & {$[1.000,1.000]$} & -.206 & {$[-.275, .275]$} & .027 & {$[-.417, .449]$} \\
\hline
\end{tabular}

\section{Appendix 4}

Results of Invariance Measurement Testing using Permutation- High level of brand experience vs. Moderated level of brand experience

\begin{tabular}{|c|c|c|c|c|c|c|c|}
\hline \multirow[t]{2}{*}{ Constructs } & \multirow{2}{*}{$\begin{array}{l}\text { Configural } \\
\text { invariance } \\
\text { (Same } \\
\text { algorithms } \\
\text { for both } \\
\text { groups) }\end{array}$} & \multicolumn{2}{|c|}{$\begin{array}{c}\text { Compositional } \\
\text { invariance } \\
(\text { Correlation }=1)\end{array}$} & \multicolumn{2}{|c|}{ Equal mean value } & \multicolumn{2}{|c|}{ Equal variance } \\
\hline & & $\mathrm{C}=1$ & $\begin{array}{l}\text { Confidence } \\
\text { Interval (CIs) }\end{array}$ & Differ. & $\begin{array}{l}\text { Confidence } \\
\text { Interval (CIs) }\end{array}$ & Differ. & $\begin{array}{l}\text { Confidence } \\
\text { Interval } \\
\text { (CIs) }\end{array}$ \\
\hline $\begin{array}{l}\text { Brand } \\
\text { Experienc }\end{array}$ & Yes & .999 & {$[.999,1.000]$} & 241 & {$[-.254, .243]$} & .047 & {$[-.328, .319]$} \\
\hline Sensori & Yes & 1.000 & {$[1.000,1$} & .194 & & -.022 & {$[-.343, .381]$} \\
\hline Affective & Yes & 1.000 & {$[.999,1.000]$} & .306 & {$[-.240, .236]$} & .073 & {$[-.295, .283]$} \\
\hline Intellectual & Yes & .999 & {$[.998,1.000]$} & .022 & {$[-.241, .224]$} & . 126 & {$[-.244, .267]$} \\
\hline
\end{tabular}




\begin{tabular}{|c|c|c|c|c|c|c|c|}
\hline Behavioral & Yes & 1.000 & {$[.998,1.000]$} & .341 & {$[-.243, .230]$} & .066 & {$[-.288, .331]$} \\
\hline Social & Yes & .999 & {$[.997,1.000]$} & .194 & {$[-.232, .231]$} & -.119 & {$[-.315, .309]$} \\
\hline $\begin{array}{l}\text { Brand } \\
\text { Trust }\end{array}$ & Yes & 1.000 & {$[1.000,1.000]$} & .451 & {$[-.229, .233]$} & -.183 & {$[-.462, .470]$} \\
\hline Competence & Yes & 1.000 & {$[1.000,1.000]$} & .445 & {$[-.232, .226]$} & -.230 & {$[-.498, .507]$} \\
\hline Benevolence & Yes & 1.000 & {$[1.000,1.000]$} & .414 & $6, .247]$ & -.141 & $75, .396]$ \\
\hline $\begin{array}{l}\text { Brand } \\
\text { Attachment }\end{array}$ & Yes & 1.000 & {$[1.000,1.000]$} & .246 & {$[-.237, .250]$} & -.250 & {$[-.362, .395]$} \\
\hline Affection & Yes & 1.000 & {$[.999,1$} & .381 & {$[-.232, .227]$} & -.385 & {$[-.385, .421]$} \\
\hline Passion & Yes & 1.000 & {$[1.000,1.000]$} & .219 & {$[-.261, .223]$} & -.144 & {$[-.333, .341]$} \\
\hline Connection & Yes & 1.000 & {$[1.000,1.000]$} & .090 & {$[-.234, .229]$} & -.102 & {$[-.337, .367]$} \\
\hline
\end{tabular}

